\title{
The Current Picture of the Transition to a Green Economy in the EU-Trends in Climate and Energy Policy versus State Security
}

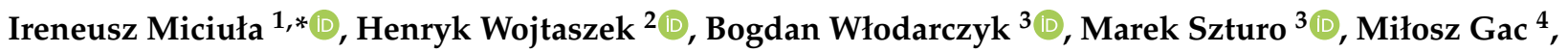 \\ Jerzy Będźmirowski ${ }^{5}$, Katarzyna Kazojć ${ }^{6}$ and Judyta Kabus ${ }^{7}$ \\ 1 Department of Sustainable Finance and Capital Markets, Institute Economics and Finance, University of \\ Szczecin, 71-101 Szczecin, Poland \\ 2 Department of Management and Command, Institute of Management, War Studies University, \\ 00-910 Warsaw, Poland; h.wojtaszek@akademia.mil.pl \\ 3 Department of Finance, Faculty of Economic Sciences, University of Warmia and Masuria in Olsztyn, \\ 10-720 Olsztyn, Poland; bogdan.wlodarczyk@uwm.edu.pl (B.W.); marsz@uwm.edu.pl (M.S.) \\ 4 Faculty of Finance and Management, WSB University in Gdańsk, 80-266 Gdańsk, Poland; mgac@wsb.gda.pl \\ 5 Department of Command and Naval Operations, Department of Safety Sciences, Naval Academy Heroes of \\ Westerplatte in Gdynia, 81-127 Gdynia, Poland; jbedzmirowski@amw.gdynia.pl \\ 6 Department of Enterprise Management, Institute of Management, University of Szczecin, \\ 71-004 Szczecin, Poland; katarzyna.kazojc@usz.edu.pl \\ 7 Department of Logistics and International Management, Faculty of Management, Częstochowa University of \\ Technology, 42-200 Częstochowa, Poland; judyta.kabus@wz.pcz.pl \\ * Correspondence: ireneusz.miciula@usz.edu.pl
}

check for updates

Citation: Miciuła, I.; Wojtaszek, H.; Włodarczyk, B.; Szturo, M.; Gac, M.; Będźmirowski, J.; Kazojć, K.; Kabus, J. The Current Picture of the Transition to a Green Economy in the EU-Trends in Climate and Energy Policy versus State Security. Energies 2021, 14, 8181. https://doi.org/ $10.3390 /$ en14238181

Academic Editor: Erik Möllerström

Received: 24 October 2021

Accepted: 2 December 2021

Published: 6 December 2021

Publisher's Note: MDPI stays neutral with regard to jurisdictional claims in published maps and institutional affiliations.

Copyright: (c) 2021 by the authors. Licensee MDPI, Basel, Switzerland. This article is an open access article distributed under the terms and conditions of the Creative Commons Attribution (CC BY) license (https:// creativecommons.org/licenses/by/ $4.0 /)$.
Abstract: This article presents the historical progression of changes and arguments indicating the need to move from fossil energy sources to the green economy in the European Union (EU) countries. It shows trends in the EU's climate and energy policy compared to the rest of the world. At the same time, it points to the elements of the necessary compromise between the climate requirements and the energy security of countries and their economies. The aim of the article is to present the main quantitative challenges for the development of the green economy in the EU, which are analyzed from the perspective of the year 2030. For this year, specific values have been established to be achieved by European countries in several fundamental areas. On the other hand, the strategic goals and further development perspective are included until 2050. This undoubtedly indicates the complexity of the issue, which is intensified as a result of the various economic and political strategies of many European Union members. At the same time, as part of the analysis carried out, efforts are made to develop concepts and practical recommendations for the development of a green European economy.

Keywords: energy and climate policy; state security; economic efficiency; European Union; sustainable development; green economy; renewable energy sources (RES); energy sources

\section{Introduction}

Energy is undoubtedly one of the fundamental factors in the development of economies around the world [1]. This is particularly evident during crises related to the reduction of supplies or the lack of energy sources. For example, the oil crisis of the 1970s of the twentieth century showed the problem of energy security, which has returned today and is one of the important topics of discussion in the European Union (EU) countries [2]. Changes in the situation of the energy markets and geopolitical conditions show that the problem of energy security is fundamental for the functioning of modern economies. It directly influences economic development and other strategic areas, including the Lisbon Strategy for Growth and Jobs and the Millennium Development Goals [3]. Therefore, the European Union takes up a number of energy challenges, the most important of which are [4]: 
- An emphasis on access to energy resources, excluding complete dependence on imports (energy security),

- The sustainable development of a competitive market of the Member States,

- Climate changes.

The EU energy and climate policy should be thought out in the long term and be beneficial for all Member States. The aim of the energy and climate policy implemented by the EU is to transform the economies of the Member States into low-energy economies. In the future, this is to ensure greater security, the sustainability of the energy used and competitiveness [5]. Therefore, it becomes important to maintain a balance between competing energy challenges, which are often mutually exclusive. Certain compromises need to be worked out, depending on many geographic, economic and social conditions. The conflict between the costly requirements in reducing greenhouse gas emissions and the creation of a competitive energy market is currently the result of the raw material possibilities and current technology. It is also necessary to develop a common position within the framework for formulating a solid and coherent climate and energy policy for the European Union countries.

The aim of article is to present the changes and trends in the contemporary climate and energy policy of the European Union and to analyze their impact on the conditions for further development for economy EU countries. The history of energy in Europe shows the need for strategic solutions in terms of the diversification of energy sources and dependence on their importation. These solutions are necessary to ensure the security of energy supplies for the economies of the Member States [6]. In addition, the situation is so complicated that various solutions should be applied for specific areas of the EU, where there are undoubtedly large differences in economic development and the use of specific energy resources. It is often also directly related to the dimension of the European Union's external action on large energy investments. This translates into opportunities to create competitive energy markets and increase energy efficiency [7].

The nature of the challenges, in the first place in the area of energy security, should lead to closer cooperation and the creation of a common European Union policy in the field of energy and climate. Undoubtedly, the joint development of the EU countries' strategy of diversifying energy sources is beneficial from every point of view. This will contribute to the development of competition, which will bring favorable economic effects and contribute to environmental protection. However, the task of limiting negative climate change must not significantly reduce economic development and the welfare of societies. Therefore, within the framework of the European Union climate and energy policy, priorities should be set if it is not possible to achieve all strategic assumptions at the same time. Indeed, attention should be paid to the limitations and feasibility of such EU policy plans for individual regions and countries, as well as the economic effects that may occur as a result of introducing unfavorable changes. An example is financial penalties or the creation of a $\mathrm{CO}_{2}$ emission allowance market, which leads to unfavorable phenomena and manipulation because it fundamentally changes the rules of management. Therefore, all regulations should allow for sustainable development of all EU Member States. Currently, the most important goal is to ensure energy security for economies but in a way that will be based on the principles of rational and efficient use of energy resources [8]. The current demand for energy resources among EU countries amounts to $16 \%$ of the energy produced in the world and, unfortunately, they have to import it to an increasing extent [9]. It is necessary that climate and energy initiatives take into account the specificity of specific regions or individual countries because, often, specific development strategies within selected energy mixes result mainly from environmental conditions [10]. In addition, a well-thought-out and stable strategy for the sustainable development of EU countries in the field of energy is supported by the economic efficiency of production and technological development, which increasingly meets the requirements of climate and ecology [11]. Therefore, the aim of the article is to analyze the history and current trends in the energy situation of European Union countries, which shows the economic losses of rapid energy reorganization for the 
purposes of the climate. Changes in the energy sector have a fundamental impact on the conditions and opportunities for the development of national economies. That is why thought-out, stable and lasting changes to energy policy are so important. Therefore, it was analyzed how to enter the path of sustainable development, using innovative technologies that often change decisions regarding the choice of a specific energy source. This allows for the conscious formation of relations between quality of life and economic growth and care for the environment, which is one of the triad goals of the European Union countries.

\section{Literature Review-Historical Picture of the Transition towards a Green Economy}

The process of European integration is the history of Europe after World War II, and the strategic raw materials at that time were coal, iron and steel. The energy policy of the EU begins with the first founding treaties, which constitute the primary rights of the European community [12] because these resources are fundamental to economic development opportunities and living standards. International institutions were established to oversee the rational use of energy resources. From 1951, the coal sector was under the control of the European Coal and Steel Community (ECSC) (due to the expiry of the 50-year validity of the Paris Treaty, the organization ceased to exist in 2002 and its competences were taken over by the European Community. Under the Treaty of Lisbon in 2009, these competences were taken over by the European Union), which in Europe until 1966 was the first among all energy resources [13]. On 25 March 1957, the European Economic Community (EEC) was established. On the other hand, as part of the common energy policy, apart from the coal community, from 1 January 1958, the nuclear industry was coordinated by the European Atomic Energy Community (EAEC, Euratom) [14].

The energy security of European countries gained particular importance during the oil crises $(1973,1979)$ because before that, most European countries had their own reserves, and imported raw materials were cheap. In addition, at that time, energy policy was not treated as an extension of foreign policy and there was the possibility of blackmailing. At that time, the sharp increase in oil prices by the OPEC countries brought the European countries closer to guarding common interests and became the basis for creating a framework for a common energy policy. Despite the fact that in the 1970s and 1980s the first strategic documents in the field of energy were drawn up, countries such as Great Britain and France preferred their own interests (individual negotiations with oil suppliers) over a common policy. Today, we have a similar situation in which individual states (Germany, Great Britain or Hungary) behave identically and prefer bilateral negotiations with Russia over the agreed policy of the EU Member States. For many years now, many European countries have not given up their sovereignty in the energy sector, despite the treaties they have signed. However, it is believed that the crises in the energy sphere played a huge role in accelerating the process of European integration. The Single European Act (SEA) entered into force on 1 July 1987 and laid the foundations for the establishment of the European Union [15]. As a result, there has been a significant development of the legal and institutional basis for further European integration. On 7 February 1992, the Treaty of Maastricht was signed, as a result of which the European Union was created. It entered into force on 1 November 1993 and was adopted for an unlimited period. Economic and monetary union was established, and the area of cooperation between member states within common policies, including in the field of energy, was expanded, especially in the field of energy carriers and the development of trans-European networks within the framework of the single internal market. However, undoubtedly, the implementation of subsequent goals and plans in the history of European integration is a difficult and multifaceted problem, which poses many difficulties among many EU members [16]. The first full framework of the EU policy in the field of energy was outlined in the White Paper-Energy Policy for the European Union of 1995 and was in force until 2005 [17]. However, the three main objectives of the energy policy outlined then (energy security, competitiveness and environmental protection) are still valid. Today they are referred to as the main triad of goals in the EU's climate and energy policy. 
The objectives of the EU energy policy were influenced by the 1994 Energy Charter Treaty and the European Energy Charter, which entered into force in April 1998. These treaties were to guarantee security of supply in the global energy market while taking into account environmental aspects. They also resulted in easier international transport as well as mutual access to technical and economic data. In 1996, the EU published the so-called The Green Book, and in 1997 the White Paper. Both books dealt with the strategy of action in relation to renewable energy sources [18]. In 1999, the Amsterdam Tactic was introduced, which introduced an orientation towards sustainable development in all aspects of the business. The common energy policy in the EU has introduced regulations enabling cooperation regarding individual energy carriers, i.e., nuclear energy under Euroatom; coal under the European Coal and Steel Community; and joint programs concerning, among others, reducing $\mathrm{CO}_{2}$ emissions and environmental protection (SAVE Program, energy tax), renewable energy sources (ALTER Program) or trans-European energy networks and technology development (JOULE-THERMIE program) [19]. On the other hand, under the provisions of the International Energy Agency (IEA), obligatory Member States must take care of the stocks of energy resources.

Every year, the European Commission conducts a statistical review of the energy situation, and every two years it publishes a strategic report on the topic of energy in the EU. The Green Paper, published on 8 March 2006, concerns the creation of a common and coherent EU energy policy [20]. The Green Paper was used to initiate consultations of the member states in order to develop the legal framework for the EU's climate and energy policy until 2030. A number of ambiguous and controversial questions were discussed in the Green Paper:

- Is it really necessary to achieve the assumed climate goals by 2030 , even at the expense of economic stability?

- How and at what cost should we ensure the competitiveness of the EU energy market?

- How should we ensure the coherence of the EU energy and climate policy, often for contradictory tasks?

- How should we take into account the geographical and developmental differences of individual EU areas [21]?

Such questions make it difficult to develop a stable action plan that will define the goals and framework for action in the energy policy until 2030 and further years. This problem shows the complexity and multidimensionality of the problems to be solved. At the same time, there are conflicts of interest between industry sectors that represent certain energy sources. Therefore, it is difficult to work out complementary goals to ensure an appropriate level of investment, which will guarantee competitive energy prices as well as greater energy security while ensuring environmental protection. In addition, the consequences of changes in the global situation (energy, political and economic) should also be taken into account, forcing the revision of achievable long-term goals, such as reducing emissions by $80-95 \%$ by 2050 [22].

At the same time, it should be noted that it happens that the EU adopts goals that are completely impossible to achieve. They are contained in official European Union regulations, which often contradict and contradict other EU objectives, for example, achieving the goal of a competitive EU energy market with insistent introduction of expensive environmental solutions and high taxes, which sometimes even exceeds the costs of purchasing energy resources. An example elsewhere is the goal of achieving a zero road-accident death toll by 2050. Undoubtedly, this means that no one will take EU regulations seriously. Additionally, the failure to implement EU regulations and their subsequent renegotiation confirm the possibility of such functioning of the EU states. Often, as part of the analysis of quantitative data, we are dealing with the lack of implementation of the goals set, and often with the so-called the creativity of the statistics of some Member States. Additionally, many EU acts and regulations have not been implemented, not only in relation to the dates that were set but also long after them. There was no assessment of the implementation of the plans, and the objectives contained in the directives were simply abandoned, which 
confirms the Member States in the need to maneuver and avoid the principles of EU provisions because in such cases these economies win. In addition, such an example comes from the leading European Union countries, such as Germany or France, which, having an economic advantage, introduce unfair rules and infringe competition, among others, through state subsidies for which other states do not receive approval.

The European Parliament issued regulation 663/2009 (entered into force on 13 July 2009) on the award of financing for projects in the field of energy. This particularly concerned three technologies, namely:

- Gas and electricity infrastructure,

- Carbon capture and storage (CCS),

- Offshore wind energy.

This shows practical development paths in the European Union's energy sector, where specific amounts are allocated to infrastructure and renewable energy sources but also to supporting clean coal technologies. This confirms the thesis that the EU policy is focused on a compromise between various energy sources and is aware of the current technological situation and the impact of geographical conditions on the development opportunities of certain countries in energy matters. Energy sources have a direct impact on the economies of states through their unquestionable impact on prices. Therefore, the diversification of energy sources is very much needed due to technological changes and geographic conditions that cause changes in the costs of obtaining energy. Since 2010, investments in transmission networks and energy connections have become a priority, which should ensure the integration of the EU energy market and energy security [23]. Investments have been estimated at EUR 200 billion [24].

The conclusions discussed confirm the decisions of the Commissioner for Energy, Günther Oettinger, who led to the easing of the EU's climate and energy policy. There has been a postponement of the implementation date of many assumptions from 2020 to 2030 . Additionally, analyzing the current situation on the EU energy market, it seems necessary to make further shifts or even a complete change of the assumed strategic numerical goals in many aspects of energy and climate [25]. Changes in the energy sector are inevitable, on the one hand, due to the depletion of certain energy sources in some countries, and on the other hand, due to the increasing impact on the climate and the environment. European Union countries, wishing to implement the triad of goals defined in the energy and climate policy, seek a compromise between market mechanisms and the necessary regulations. In order to achieve specific strategic goals, numerous regulations and regulations are introduced within the EU, which are presented in Table 1.

Table 1. The most important EU legal acts and documents concerning the main directions in the energy and climate policy for the years 2007-2019 [26-29].

\begin{tabular}{|c|c|}
\hline Legal Acts and Documents & Application Year \\
\hline European Energy Policy, COM (2007) 1 final, 2007 & 2007 \\
\hline Green Paper: Market instruments for environmental and related policy, COM (2007) 140 & 2007 \\
\hline $\begin{array}{l}\text { Communication from the Commission-European Strategic Energy Technology Plan (SET Plan). The road to } \\
\text { the low-carbon technologies of the future, COM (2007) } 723\end{array}$ & 2007 \\
\hline The Cleaner Air for Europe Directive (CAFE) Directive 2008/50/EC & 2008 \\
\hline Energy efficiency achieving the 20\% target, COM (2008) 772, 2008 & 2008 \\
\hline Directive 2009/125/EC on ecodesign for energy-related products & 2009 \\
\hline $\begin{array}{c}\text { Directive 2009/28/EC on the promotion of the use of energy from RES, setting a target of } 20 \% \text { share of } \\
\text { energy from renewable sources by Member State. }\end{array}$ & 2009 \\
\hline White Paper: Adaptation to climate change, a European framework for action, COM (2009), 147 & 2009 \\
\hline
\end{tabular}


Table 1. Cont

\begin{tabular}{|c|c|}
\hline Legal Acts and Documents & Application Year \\
\hline $\begin{array}{l}\text { Directive 2010/75/EU of the European Parliament and of the Council on industrial emissions } \\
\text { ("IED Directive") }\end{array}$ & 2010 \\
\hline Directive 2010/31/EU on the energy performance of buildings & 2010 \\
\hline Communication from the European Commission-Energy 2020, COM (2010) 639 & 2010 \\
\hline $\begin{array}{l}\text { White Paper: Plan for creating a single transport area-striving to achieve a competitive and energy-efficient } \\
\text { transport system, COM (2011) 144, March } 2011\end{array}$ & 2011 \\
\hline $\begin{array}{l}\text { Green Paper: Lighting for the future-accelerating the implementation of innovative lighting technologies, } \\
\text { COM (2011) 889, December } 2011\end{array}$ & 2011 \\
\hline $\begin{array}{l}\text { Directive 2012/27/EU of the European Parliament and of the Council of } 25 \text { October } 2012 \text { on energy } \\
\text { efficiency, amendments to Directives 2009/125/EC and 2010/30/EU }\end{array}$ & 2012 \\
\hline Green Paper: A 2030 framework for climate and energy policies, COM (2013) 169 & 2013 \\
\hline Implementation plan for European infrastructure projects in energy, COM (2013) 791, 2013 & 2013 \\
\hline European Energy Security Strategy, COM (2014) 330 final, May 2014 & 2014 \\
\hline Conclusions on the 2030 climate and energy policy framework, SN 79/14, 24 October 2014 & 2014 \\
\hline Strategy for the Energy Union & 2015 \\
\hline EU greenhouse gas emission allowance trading scheme-EU ETS & 2015 \\
\hline Assessment of policy options for the review of Directive 2010/31/EU & 2016 \\
\hline $\begin{array}{c}\text { The energy sector as one of the pillars of growth, competitiveness and development for modern economies. } \\
\text { EU energy in numbers. }\end{array}$ & 2017 \\
\hline The role of trans-European gas infrastructure in the light of the decarbonization goals & 2017 \\
\hline New rules on renewable energy, energy efficiency and management & 2018 \\
\hline The EU's low-carbon strategy until 2050 & 2018 \\
\hline $\begin{array}{c}\text { Directive (EU) 2019/944 of the European Parliament and of the Council of } 5 \text { June } 2019 \text { on common rules for } \\
\text { the internal market in electricity }\end{array}$ & 2019 \\
\hline $\begin{array}{c}\text { Directive (EU) 2019/692 of the European Parliament and of the Council of } 17 \text { April } 2019 \text { concerning common } \\
\text { rules for the internal market in natural gas }\end{array}$ & 2019 \\
\hline
\end{tabular}

Geopolitical, environmental and technological changes force changes to the laws and regulations in the energy policy. This shows the complexity of the legislative process, which is not conducive to the effective implementation of the introduced changes.

The main challenges and perspectives for the development of the European Union's climate and energy policy are set out in a detailed set of regulations on:

- Strategic challenges related to: the globalization of energy markets and the dependence of EU countries on external markets, technologies for generating energy from available sources in EU countries, defining institutional responsibility in the field of energy security and counteracting climate change [30],

- Trends in the development of energy in the global and EU context, including in particular: stability of the geopolitical situation, the volume of supply and demand for energy in the world and in the EU, innovative technologies of production from renewable energy sources, and low-emission coal and gas technologies [31],

- Guidelines for implementing energy policy in the perspective of 2030 and 2050, i.e., integration of the energy market in the EU, increase in energy independence, diversification of energy sources (energy mix), sustainable development, research and development of energy technologies, energy efficiency [32] and the use of new instruments and solutions of the European Union climate and energy policy.

The European Commission communication “Energy 2020, a strategy for competitiveness, sustainable development and energy security" again points to the so-called the triad 
of EU goals in the climate and energy policy but with the shift of gravity towards the security of energy supplies [33]. After the recession ends, energy demand is expected to increase rapidly. The new strategy is designed to prevent interruptions in energy supplies, which will translate into supporting economic growth. For the implementation of many tasks of the EU energy policy, an action plan is necessary to create and develop an integrated European energy network. For its implementation, the so-called Infrastructure Package has been devised, which will enable the fulfillment of other strategic tasks. The European Commission is to ensure clear rules for investments in this area, as well as indicate solutions that will support innovative low-carbon technologies [34]. This is because the frequent lack of agreement between the EU Member States as to strategic goals results in the lack of implementation of the set tasks and constant changes in laws and regulations. Undoubtedly, the constant changes in strategic solutions do not contribute to the effective fulfillment of EU regulations in a timely manner, although it is known that the issue itself is complex and ambiguous. This is confirmed by the European Council itself, which in the note SN 79/14 reserved the possibility of changes in the energy and climate policy until 2030 depending on the current situation [35].

Too high emissivity of individual economies is a contemporary climate challenge for the modern world. Working out a compromise by the energy mix for the implementation of the so-called the triad of European Union policy goals has a direct impact on the economic situation of the EU countries. In order to carry out an appropriate analysis, the history of the energy sector in European countries and the assessment of the state of the energy sector in the EU countries against the background of the world are presented. The research methods used for the discussed analyses and developed recommendations are a review of the world literature on the subject in question and a statistical analysis of quantitative data of the largest statistical organizations in the world. The goals and tasks for the energy sector until 2050 result from many historical and geographical conditions and create areas of significant differences within European countries. The article provides a historical overview of changes and developments in the energy sector. Additionally, by analyzing the practices of EU countries through the prism of empirical quantitative data collected by the world's largest organizations and institutions, such as the International Energy Agency (IEA), the World Nuclear Association (WNA) and European Statistical Office (Eurostat), it presents recommendations for the future climate and energy policy. Conclusions resulting from the implementation of the discussed research methods are presented in accordance with the current economic efficiency of various energy sources.

\section{The Current Green Economy Situations in European Union}

Coal consumption in virtually all systems and categories increased very dynamically in the first 15 years of the 21st century, in a global, continental and geopolitical systems. Coal consumption was limited only by those countries of the Europe that had exhausted most of their resources, i.e., Belgium, France, Great Britain, or in the case of hard coal only-Germany. The world has been developing energetically at a fast and stable pace for over half a century. Overall, energy consumption has increased since 1965 from 3750 to 12,685 million toe in 2012. According to the forecast for the global energy market, the energy efficiency of all global installations is to increase from 5640 gigawatts (GW) in 2012 to 9266 GW in 2030. Over the same period, electricity production is expected to increase from 22,441 terawatt hours (TWh) to 34,458 TWh [36]. The biggest difference is the consumption of coal, which in Europe is decreasing; worldwide, it is growing, with the fastest growth occurring in the 21st century [37]. While in 2000 the whole world consumed a total of 2350 million tons of coal converted as oil equivalent (toe), in 2012 it was already 3910 million toe, which means nearly a $70 \%$ increase over 12 years [38]. The most spectacular growth took place in China, where coal consumption increased by more than 200 percent in 12 years. At the current level of extraction, the documented reserves of domestic coal will suffice the Chinese for half a century. Other Asian tigers, such as India and Indonesia, are recording similar increases in consumption. 
With regard to the energy industry, different trends can be noticed between the European market and the world [39]. While gas energy will record growth in both markets, the potential of coal energy will be characterized by a significant increase globally, and by a decrease in Europe. The share of coal-based energy will decline in different regions of the world for different reasons-in North America, due to the possibility of extracting rich shale gas deposits, and in Europe after 2020, as a result the entry into force of new legislation on emission levels. This also results from the exhaustion of hard coal resources in some developed countries of Western Europe. Power generation levels from all three of the main fuels are expected to be higher and, in addition, projections indicate that coal will become the dominant fuel. Currently, it constitutes almost 30\% of the power of existing installations, and in 2030 it may reach the level of approximately 35\% of the amount of energy produced and globally will again become the main energy resource [40]. Gas is also expected to catch up quickly and gain even more importance. The current level of use of various energy sources is shown in Figure 1.

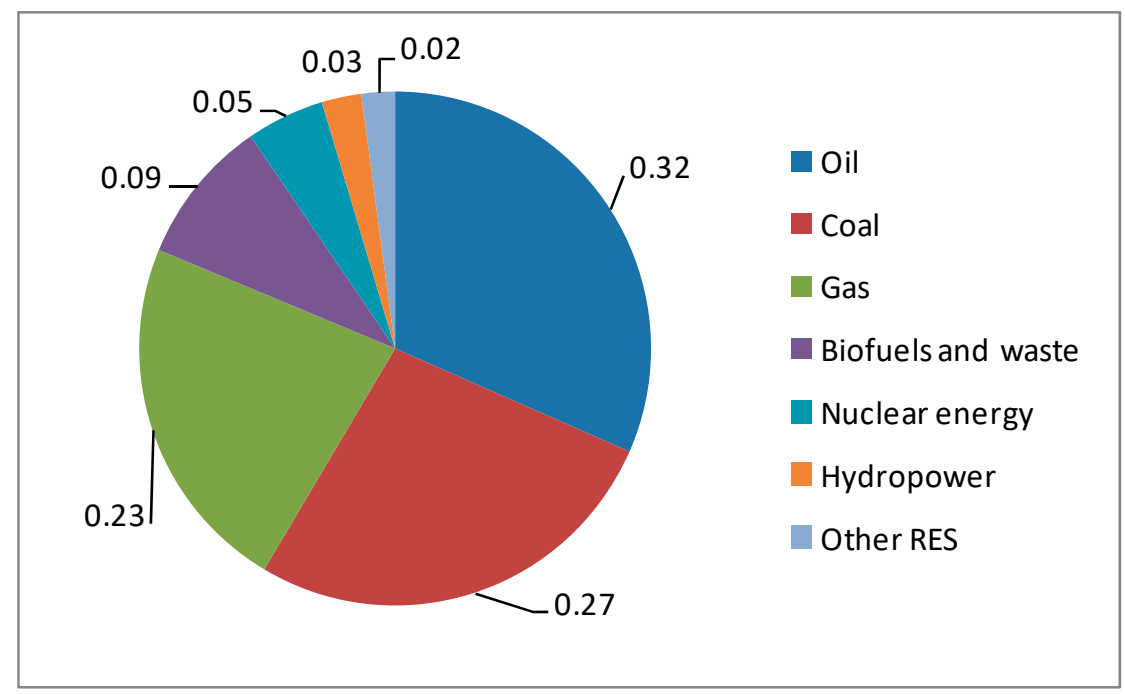

Figure 1. Energy from various sources in the world in 2018 (in terms of percentage) [41].

Looking at information from modern media, it seems that renewable energy sources produce a large amount of energy. However, this is only an impression created by the lobby of Western European countries, for which there is no other option but to invest in this type of energy source. The statistics of quantitative data on the consumption of primary energy sources in the 21st century indicate a completely different reality. Indeed, we can see that non-renewable energy sources such as oil, natural gas and coal still dominate. The percentage breakdown of energy use is currently stagnating due to the emergence of more alternatives and market saturation. Forecasts until 2030 show that oil will play a smaller role in the basket of energy sources, and, temporarily, coal will again become dominant in the world. From the perspective of 2050, gas will also be of great importance. Coal is the most dynamically developing energy source in the 21st century, followed by gas. By analyzing the situation of energy sources since 2000, it is possible to determine the percentage dynamics of the increase in the consumption of individual raw materials, which result from changes counted in million toe. Overall, energy consumption increased by $35.7 \%$, and the increase in individual energy commodities was as follows [42]:

- $70.2 \%$ coal;

- $51.4 \%$ natural gas;

- $19.5 \%$ hydropower;

- $16.8 \%$ crude oil;

- $6.3 \%$ nuclear energy. 
The upturn in coal is the result of the need to provide energy for the rapid economic development of China and other Asian countries, as well as the increase in production in most countries of the world. In the case of gas, it results from the need for more clean and flexible production systems and from the increase in the level of global production. In North America, this happened due to the discovery of rich shale gas deposits. At the same time, the forecasts indicate the rapid development of gas energy in China and the Middle East. Additionally, the European Union, where voices about "impurity" of coal are the loudest, in statistical terms has increased its consumption since 2010, and these values have returned to the level from the beginning of the 21st century, despite the "clean" policy and resource depletion in some EU countries [43]. This shows the ineffectiveness of the EU's actions or the irrationality of the adopted policy, which was adopted for other hidden goals of the main states that determine its shape.

Analyzing the share of energy consumption by Europe in the global balance, one can see a sharp decline in the share of EU countries in world consumption, from $26 \%$ in 1965 to less than 13\% in 2018 [44]. The economies of the rich countries of Western Europe are saturated, and the countries of Central and Eastern Europe are not making up for backlog at the same pace as the developing countries of the world, especially Asia. In addition, there was a pandemic crisis and we are now dealing with stagnation in the economies of the EU Member States. Figure 2 shows the declining share of Europe in global energy consumption.

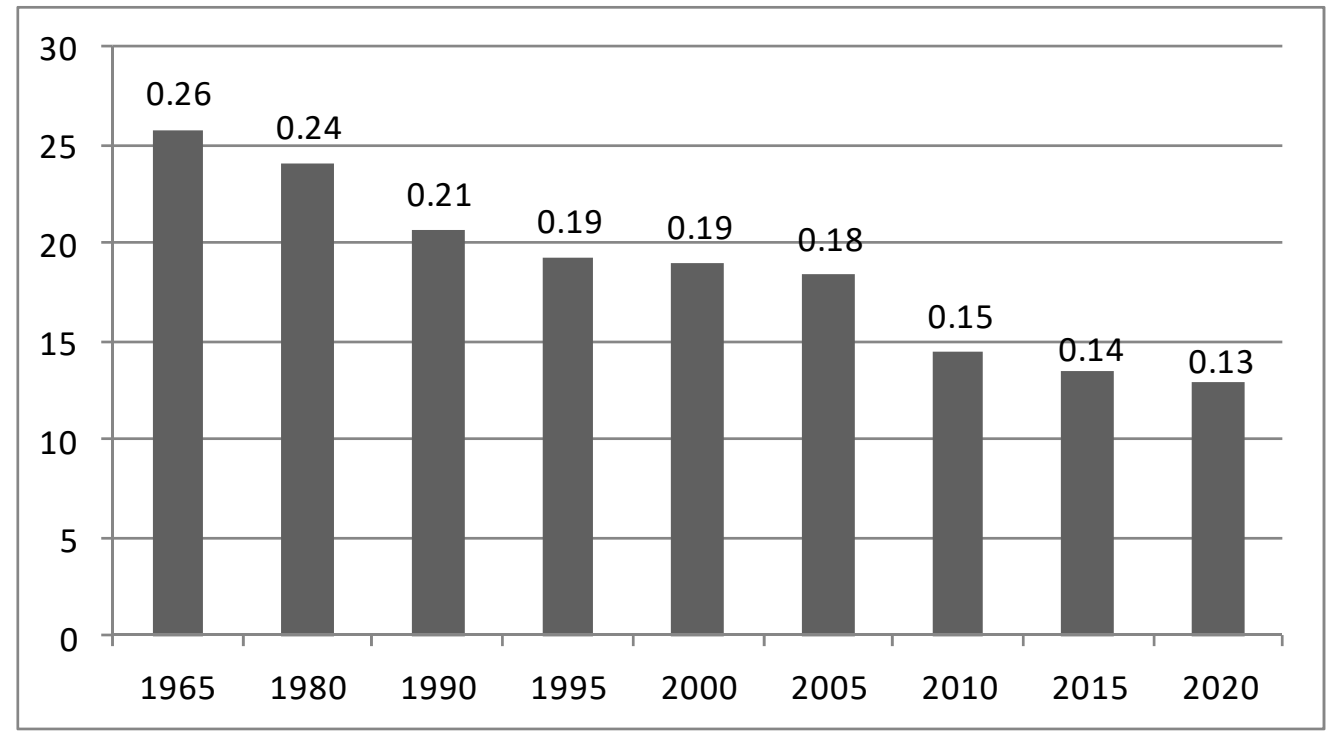

Figure 2. Europe's share of global energy consumption (in \%) [41,42].

Europe is an ever-smaller player in the global energy market. This is also visible in the analysis of the share in the global use of the three main energy sources that best indicate energy trends in Europe. The percentage of crude oil consumption decreased from $29 \%$ in the 1970 s to $14 \%$ in 2018 [41]. The share of gas, after a sharp increase until the early 1980s, when it was $19 \%$, had a long period of stability, only to drop to $12 \%$ in 2018 after 2005. However, the largest decrease was recorded by coal, as in 1965 Europe consumed $36 \%$ global balance sheet and in 2018 less than $8 \%$ [42]. This is a persistent trend that shows the need for energy consumption in other, rapidly developing regions of the world, as well as stagnant economies and energy problems in EU countries. When analyzing hard coal resources in the EU countries, it can be said that the era of hard coal mining in the absence of the discovery of new deposits naturally ended as a result of resource depletion. Poland should only be omitted, which currently has approximately $85 \%$ of all hard coal resources among the European Union countries (Figure 3). 


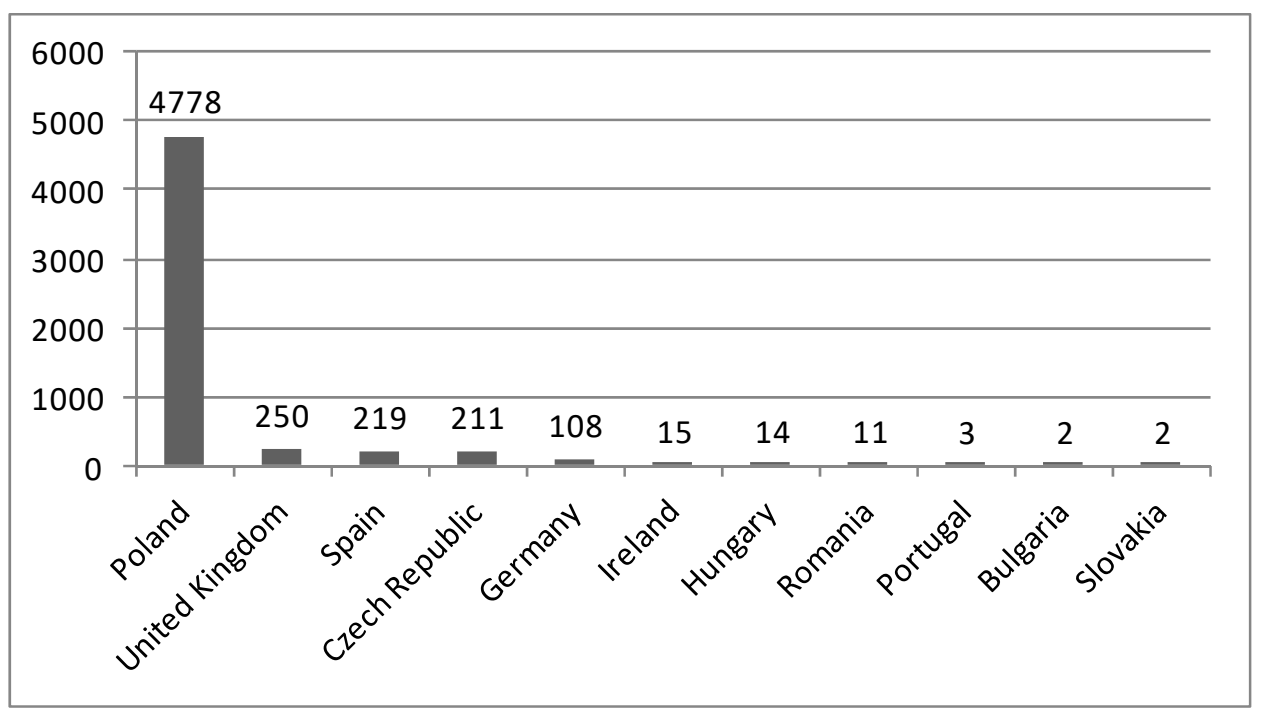

Figure 3. Hard coal resources in EU countries in 2018 (million tonnes) [45].

The strategy of energy policy in the global and EU context must be based on comprehensive detailed analyzes. For example, conclusions for the coal industry should be drawn from the analysis of all types of coal currently available because often in the literature on the subject you can find analyses based solely on hard coal resources, which may cause wrong strategic decisions in the energy policy (hard coal contains $75-97 \%$ carbon element and a calorific value between 17 and $30 \mathrm{MJ} / \mathrm{kg}$. For comparison, the calorific value of pure carbon is approximately $33.2 \mathrm{MJ} / \mathrm{kg}$ ). The best examples are the EU Member States, where the energy and climate policy, at least in theory confirmed by EU legal acts, aims to limit coal as an energy resource due to excessive carbon dioxide emissions. On the other hand, practice, i.e., statistical data, shows something completely different, and despite the exhaustion of hard coal resources, coal consumption continues to increase. In addition, forecasts indicate that, as in the world, also in EU countries, coal consumption will grow, despite the policy of limiting so-called "Dirty" energy, i.e., energy that emits a significant number of greenhouse gases [46]. Germany is an excellent example of this issue. The country that is most responsible for the direction of the contemporary EU climate and energy policy, due to the influence of the Green party, is at the same time the largest coal producer in Europe, and in terms of lignite mining (lignite has a carbon content of $62-75 \%$ and a calorific value between 7.5 and $21 \mathrm{MJ} / \mathrm{kg}$, but, for example, drying the raw coal can bring this value up to $29 \mathrm{MJ} / \mathrm{kg}$ ) is the largest in the world (Figure 4). Additionally, investments in the construction of another six lignite mines has commenced, which will further strengthen Germany as a world leader [47]. Therefore, in the coming years, lignite mining in Germany will exceed 200 million tons per year.

Therefore, action strategies in the EU countries should be developed taking into account the investments carried out in practice, including in Germany, which differ from the arrangements for energy policy. In addition, Germany, which in terms of value has the largest share of carbon dioxide emissions among EU countries, generates almost $50 \%$ of electricity from coal, including over 30\% from less efficient lignite [47]. For the economy, this will act as compensation for the high costs of green energy and ensure the security of electricity supply in the event of fluctuations in RES production [48]. Therefore, a rational energy policy has been implemented, which is contrary to the decisions of the EU. Problems in the EU energy and climate policy result from contradictory goals and failure to adhere to the developed policy and the lack of rich deposits of the main energy sources. Figure 5 shows the top 10 richest countries in the world with the three main energy resources.

Global data leave no doubt that, according to the forecasts in the 21st century, coal will again become the first energy resource in the world. This tendency is confirmed by the 
world's carbon resources, which are globally evenly distributed and constitute $60 \%$ of the basket of the three main energy sources of the modern world (Figure 6).

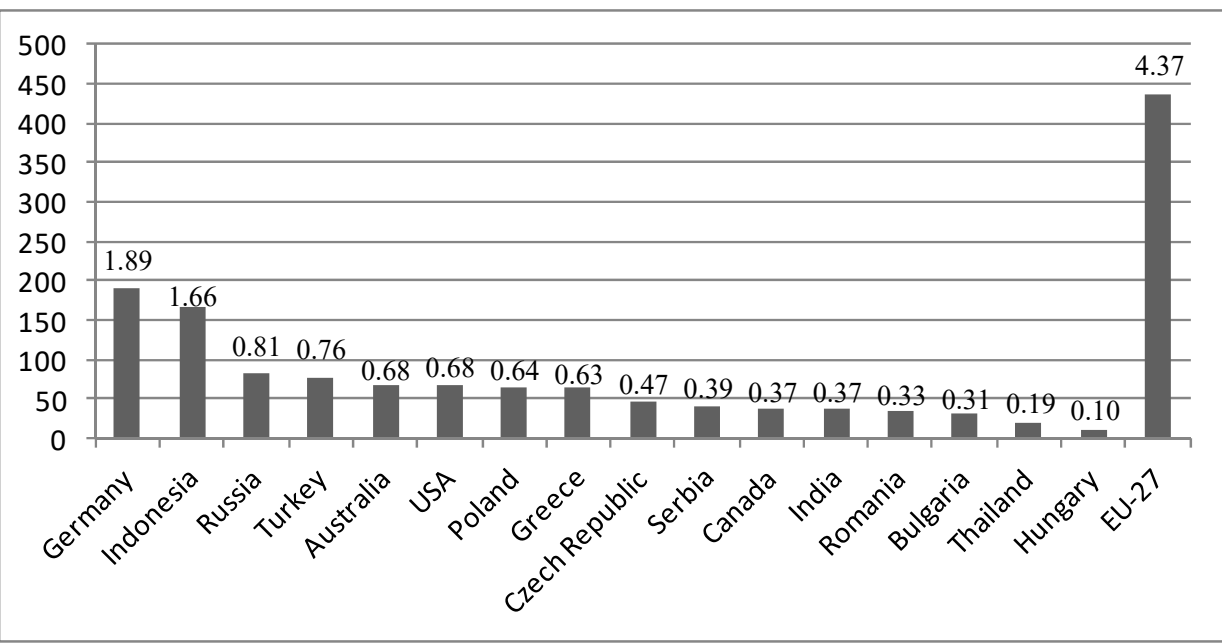

Figure 4. Lignite mining in the world in 2018 (million tons) [47].

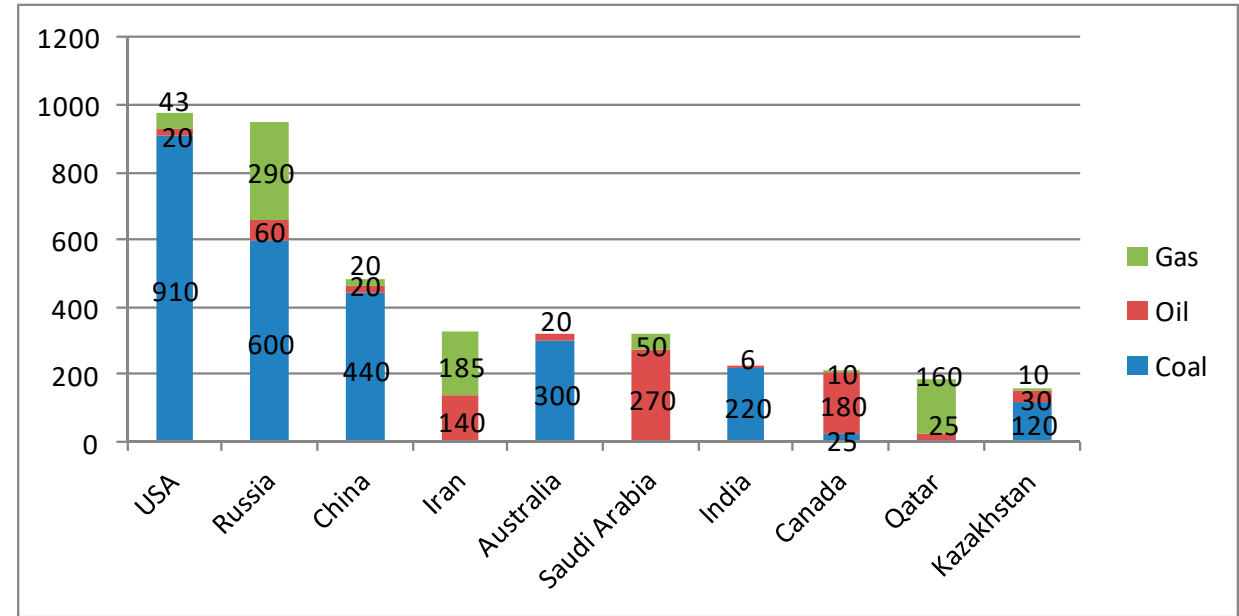

Figure 5. The ten richest countries in the world in energy resources (billion toe) $[48,49]$.

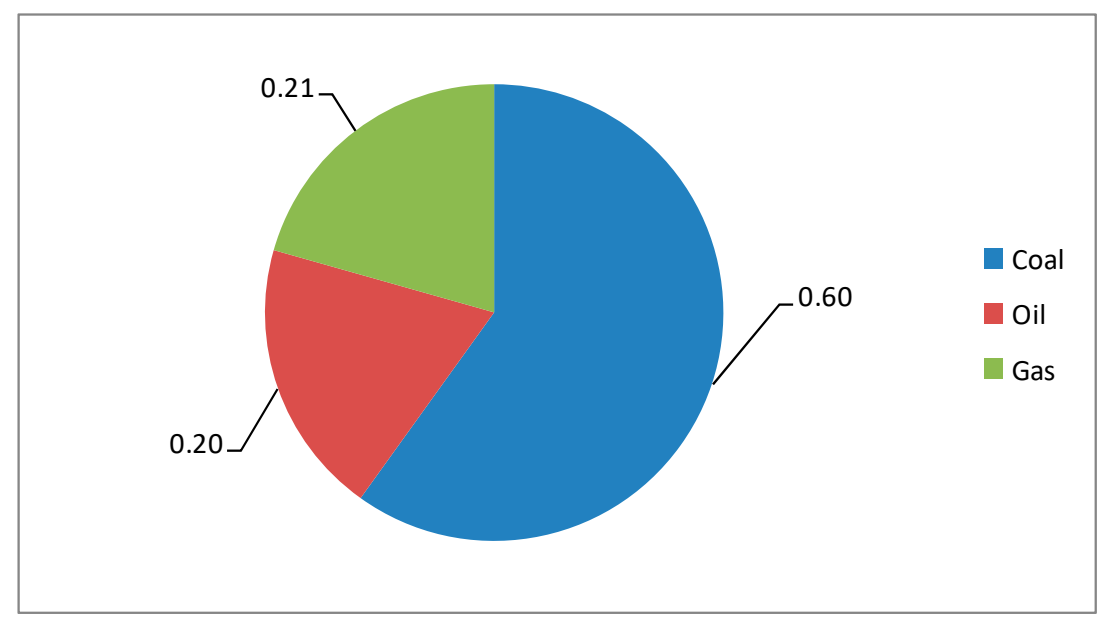

Figure 6. World resources of the three main energy raw materials (in terms of percentage) [41]. 
The current geopolitical situation requires the implementation of fundamental investments in energy infrastructure (for example, the Nabucco project) in order to diversify the directions of supplies and the possibility of selecting energy sources on a market basis [50]. This has a direct impact on the strategic aspects of the security of energy supplies for national economies. The significance of these investments is confirmed by quantitative data indicating the current dependence of EU countries on Russia, which undoubtedly results in a lack of security and competitiveness (Table 2) [41] and constitutes an element of direct political and economic pressure.

Table 2. The dependence of individual EU Member States on gas imports from Russia [41].

\begin{tabular}{cccc}
\hline \multirow{2}{*}{ Country } & \multirow{2}{*}{$\begin{array}{c}\text { Gas Imports from } \\
\text { Russia (Billion } \mathbf{~ m}^{3} \text { ) }\end{array}$} & \multicolumn{2}{c}{ Dependence on Imported Natural Gas from Russia } \\
\cline { 3 - 4 } & & Share in Consumption & Import Share \\
\hline Lithuania & 3.72 & $100.0 \%$ & $100 \%$ \\
Slovakia & 6.22 & $100.0 \%$ & $99.20 \%$ \\
Estonia & 0.85 & $100.0 \%$ & $100 \%$ \\
Finland & 4.58 & $99.9 \%$ & $100 \%$ \\
Latvia & 1.64 & $96.5 \%$ & $100 \%$ \\
Czech Republic & 6.8 & $78.9 \%$ & $78.80 \%$ \\
Bulgaria & 2.8 & $78.6 \%$ & $100 \%$ \\
Greece & 3.16 & $77.6 \%$ & $77 \%$ \\
Austria & 5.4 & $64.0 \%$ & $55.90 \%$ \\
Hungary & 7.85 & $58.8 \%$ & $75.10 \%$ \\
Slovenia & 0.59 & $58.0 \%$ & $58.20 \%$ \\
Poland & 6.86 & $41.8 \%$ & $67.70 \%$ \\
Germany & 38.3 & $39.3 \%$ & $43.30 \%$ \\
Romania & 4.5 & $28.2 \%$ & $86 \%$ \\
Italy & 22.6 & $26.7 \%$ & $30.70 \%$ \\
France & 5.7 & $13.4 \%$ & $13.30 \%$ \\
\hline
\end{tabular}

Due to the dependence of European countries on external supplies, the current energy strategy is aimed at gaining access to the entire energy market thanks to infrastructure investments and greater use of own resources thanks to technological innovations. Figure 7 shows the current share of low-emission energy sources in electricity production in selected European Union countries.

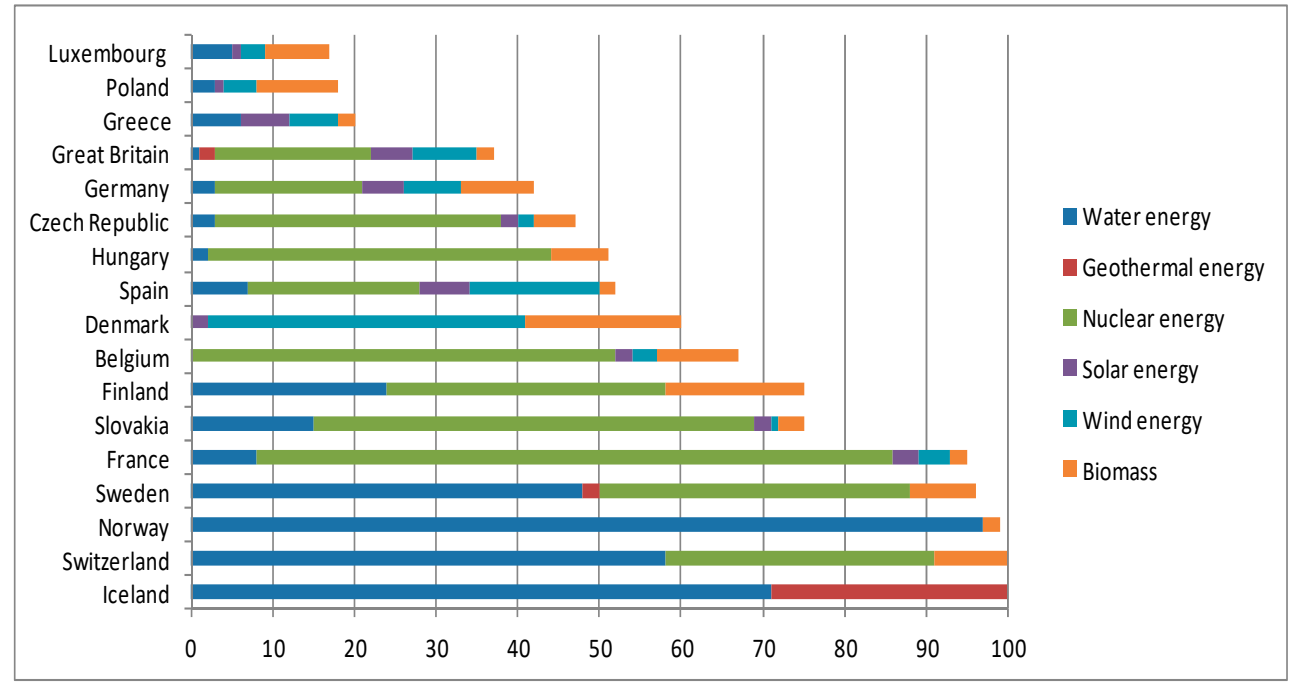

Figure 7. Share of low-emission sources in electricity production in 2018 (in terms of percentage) $[51,52]$. 
Analyzing the above data, we see large limitations in the use of low-carbon energy sources. Some countries in Europe already have a structure of energy sources in line with the EU ideal, while we have very high values for the use of renewable energy. For example, these are: Iceland, where $100 \%$ is hydro and geothermal energy, Norway, where $95 \%$ of the needs are met by hydropower; Switzerland, where $60 \%$ is hydropower and $35 \%$ nuclear; and Sweden, where $50 \%$ is hydro and $40 \%$ nuclear [51]. Austria also has high values of renewable energy use thanks to $62 \%$ share of hydropower; Finland, thanks to a $25 \%$ share of hydropower and 35\% of nuclear energy; and France, which satisfies as much as $80 \%$ of the needs from nuclear energy [52]. However, these countries achieved shares of low-carbon energy based on natural geographic conditions and already had them before the EU targets for the share of RES in the energy mix. This analysis shows that natural geographic conditions, such as large water bodies and topography, naturally allowed some EU countries to achieve this structure of the energy mix. On the other hand, further percentages in this structure are due to investing in nuclear energy [53].

On the other hand, it should be noted that there are countries that have made significant progress in achieving greater importance of renewable sources in the energy mix. The countries such as Portugal (17\% change), Denmark ( $15 \%$ change), Spain ( $11 \%$ change) and Ireland (10\% change) achieved the most significant changes after establishing the EU strategy for the objectives of low-carbon energy sources [52]. However, when undertaking a detailed analysis of the changes, we will see that all these countries owe these changes thanks to the wind energy that was already present in their energy mixes. Therefore, we can see that it was natural conditions that decided about the possibility of increasing this share, and there was only a shortage of funds for these investments. An interesting example is Germany, which, despite huge investments in renewable energy, increased its share of low-carbon energy only from $38 \%$ to $42 \%$, because it also partially gave up nuclear energy [51]. Therefore, other countries that will not have adequate natural opportunities and lack investments in nuclear energy will have a similar share of RES as Greece, Poland and Luxembourg [54]. As a result, some countries are particularly disadvantaged in terms of the need to implement the EU climate package. Figure 8 shows the percentage of renewable energy sources in the EU-27.

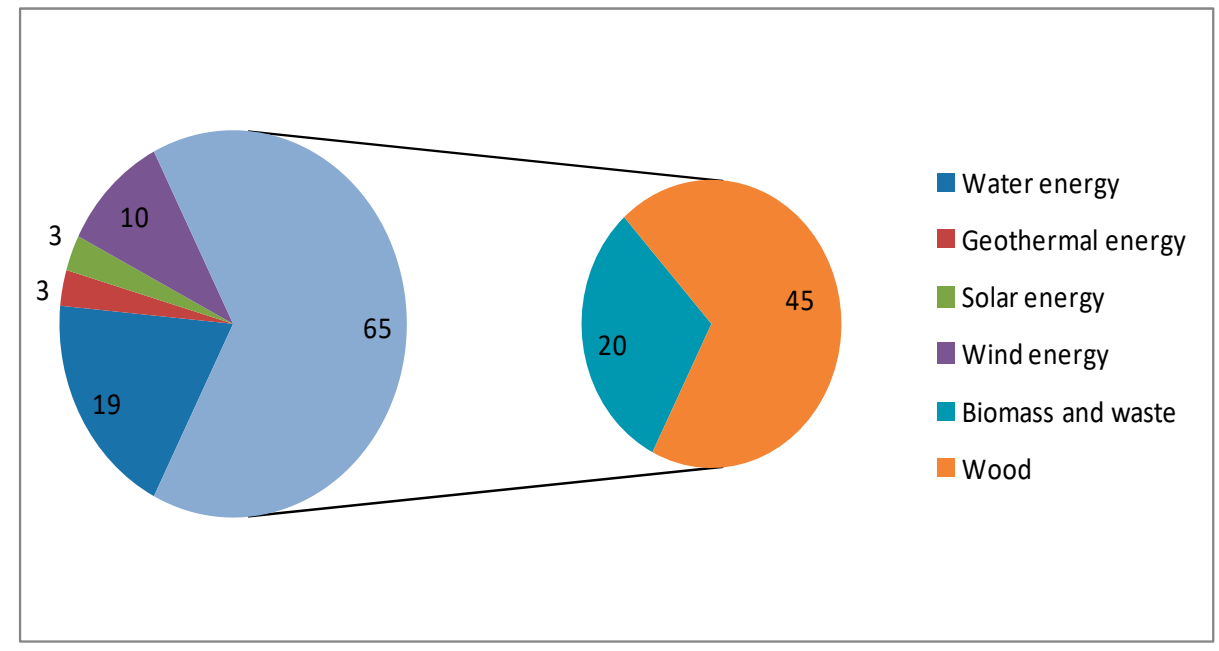

Figure 8. RES consumption for the EU-27 in 2019 (in terms of percentage) [55].

The above data confirm the limited applicability of RES; $65 \%$ of the mix is wood $(45 \%)$ and other biomass and waste $(20 \%)$. Hydropower has a significant share $(19 \%)$ and the use of wind energy is increasing (10\%) [55]. Global promotion for the complete conversion to the use of renewable energy in the current state of technology is unjustified. Practice proves that there is no logical justification for using renewable energy sources where it is not profitable. In addition, with some RES, there may be problems with meeting energy demand due to changing weather conditions. Additionally, paradoxically, the 
analyses show that it is also not significantly beneficial for climate protection. There are several reasons for this, including that biomass combustion and deforestation constitute $10 \%$ of greenhouse gas emissions. The global emission of 30 billion tons of $\mathrm{CO}_{2}$ annually gives 4.5 tons of $\mathrm{CO}_{2}$ per person [41]. A tree absorbs about $5 \mathrm{~kg}$ of $\mathrm{CO}_{2}$ per year on average [42]. These calculations show that it takes up to a thousand trees to cut emissions per person. Undoubtedly, forests are an indispensable factor of ecological balance and the neutralization of pollutants. Therefore, the protection of forests is an indispensable condition for limiting environmental degradation. The current EU regulations cause additional transport of biomass, which increases $\mathrm{CO}_{2}$ emissions. According to the data of the Intergovernmental Panel on Climate Change (IPCC), the main reasons for the decrease in oxygen concentration in the atmosphere and increase in $\mathrm{CO}_{2}$ concentration outside energy and industrial processes are followed by transport, burning biomass and deforestation [47], which is confirmed by Figure 9.

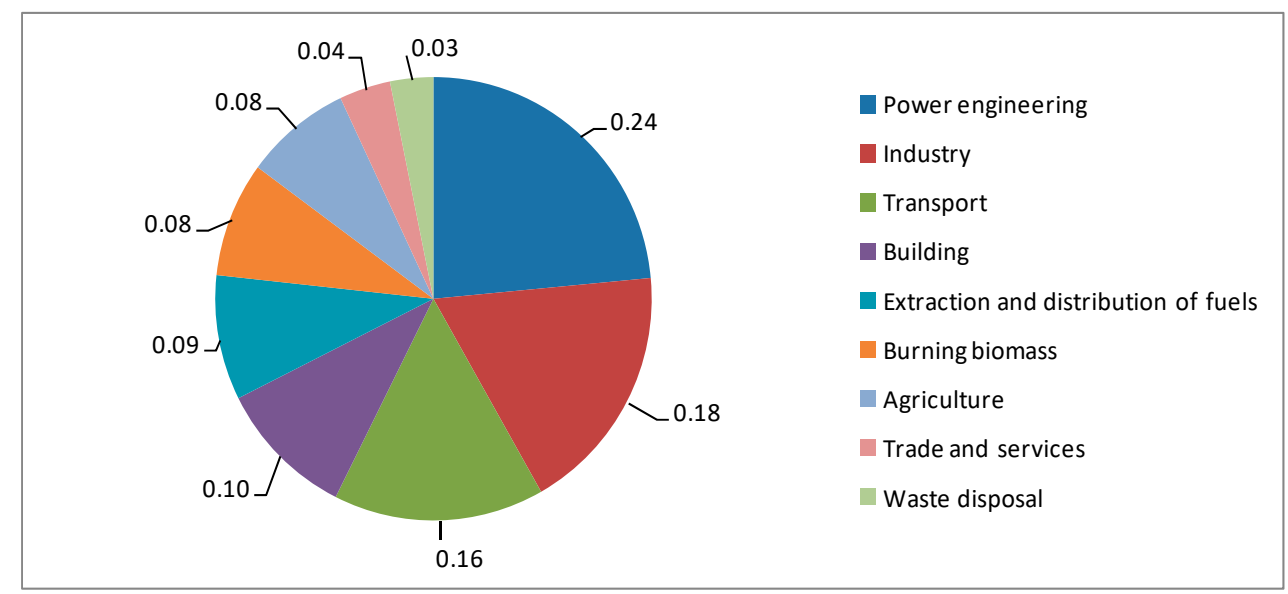

Figure 9. Sources of greenhouse gas emissions by sectors of the economy in 2019 [56].

When analyzing in detail the data on achieving the target of using $20 \%$ RES in EU countries, it should be stated that it is associated with high costs and leads to many unfavorable phenomena. Additionally, these changes are primarily unstable. The desire to reduce $\mathrm{CO}_{2}$ emissions resulted in the co-financing of energy crops, which often was not profitable without subsidies, and at the same time they were used as an additive to co-combustion with fossil fuels in power plants. In practice, the $\mathrm{CO}_{2}$ balance is much less favorable than it may appear from calculations, due to emissions during production (e.g., processing into pellets) and transport of biomass [57]. Due to insufficient supply in Europe and higher prices, the practical consequence of these regulations is the import of biomass from outside the EU, e.g., from Africa, Asia and South America, which negates the benefits associated with reducing emissions [58]. Green policies and investments in RES lead to many unexpected paradoxes, namely:

- Increasing "dirty" energy. An example is German suppliers who, in order to offset the costs of RES, buy the cheapest, and therefore the dirtiest, lignite-based electricity. In addition, taking into account efficiency, lignite is already used to generate $30 \%$ of energy in Germany, and new units are being built to ensure a constant source of electricity in the event of fluctuations in production from RES. This is called the "energy transformation paradox"—despite the increase in the share of RES in energy consumption, $\mathrm{CO}_{2}$ emissions are growing [59]:

- Expensive energy-RES technologies will be expensive for a long time to come. In Germany, as a result of the largest investments in green energy, the price of electricity is the highest in Europe, and statistics show that over 300,000 households are disconnected from the grid for unpaid bills. This phenomenon is known as "energy poverty". 
- The long-term carbon footprint, which is greater for some green technologies than for the dirty old ones. For example, electric cars are extremely harmful to the environment due to the huge number of installed batteries.

- The EU regulations consider the electricity generated from the co-combustion of coal with biomass (mainly wood) to be clean. The energy industry has received a good deal, so wood from other parts of the world is flowing into Europe at a great rate, so much so that new sawmills are being built in North America to export to Europe.

- The countries that are the world leaders in producing energy from coal invest the most in green technologies.

The above-mentioned arguments, as well as the need to ensure the security of energy supplies for the economy, meant that the " $3 \times 20$ " plan will not be implemented so rigorously [32] - certainly not in the short term, until 2030. Additionally, plans such as reducing energy consumption by $20 \%$ may turn out to be a pipe dream even in the time horizon up to 2050. Demand is certainly growing, and energy efficiency does not provide the ambitious results envisaged in the EU plans. Commissioner Oettinger said that European industry must have cheap energy to be competitive. RES are costly, unstable and require large initial investments in energy systems. Therefore, while reducing or depleting coal resources, many EU countries must to develop nuclear energy, which is already the dominant source in several countries, as shown in Figure 10.

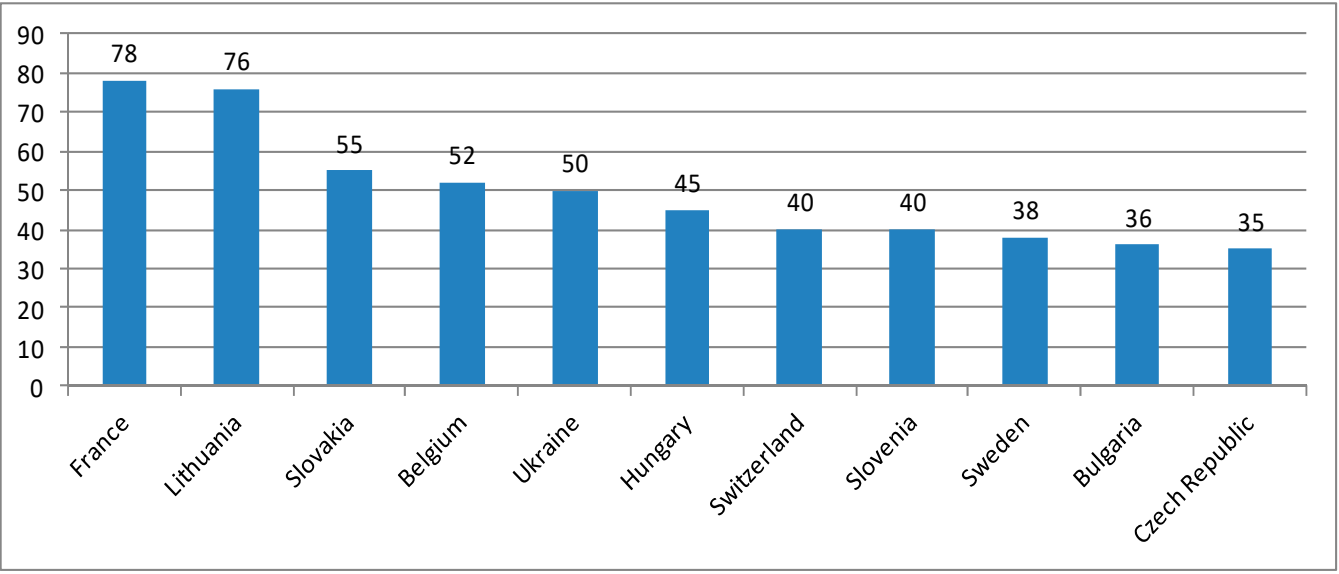

Figure 10. Share of nuclear energy in electricity production in 2018 (in terms of percentage) [47].

Everything points to Germany's return to nuclear energy, which was to be abandoned by 2022 , because with the development of renewable energy, the gas energy market is growing because electricity from wind and sun is not produced in a continuous and stable manner; therefore, gas-fired power plants that can be quickly turned on and off are necessary [60]. In Germany, the wind blows on average only $20 \%$ of the time, so the construction of windmills is really the construction of gas power plants and more efficient use of the Nordstream, and therefore greater dependence on Russian supplies. The construction of further coal-fired power plants will result in over 50\% share of coal in the energy mix for electricity production, the structure of which is shown in Figure 11.

EU policy in relation to coal and nuclear energy is not clear because the European Union did not adopt specific values to be achieved for certain Member States. The instruments of energy and climate policy (taxes, trading in $\mathrm{CO}_{2}$ emissions) have a negative impact on the competitiveness of obtaining energy from these sources [41]. By contrast, the costly subsidy of renewable energy consumes billions of subsidies that are making EU countries indebted. High prices of electricity from RES burden end consumers and directly reduce the competitiveness of EU economies [52]. This is confirmed by current events on the world stage and the statements of EU heads of government. Consequently, a return to traditional energy sources is forecast and Europe is projected to continue to depend on external supplies, especially as climate charges are reduced. Figure 12 shows 
the implementation status of greenhouse gas reduction plans by 2030 for individual EU Member States.

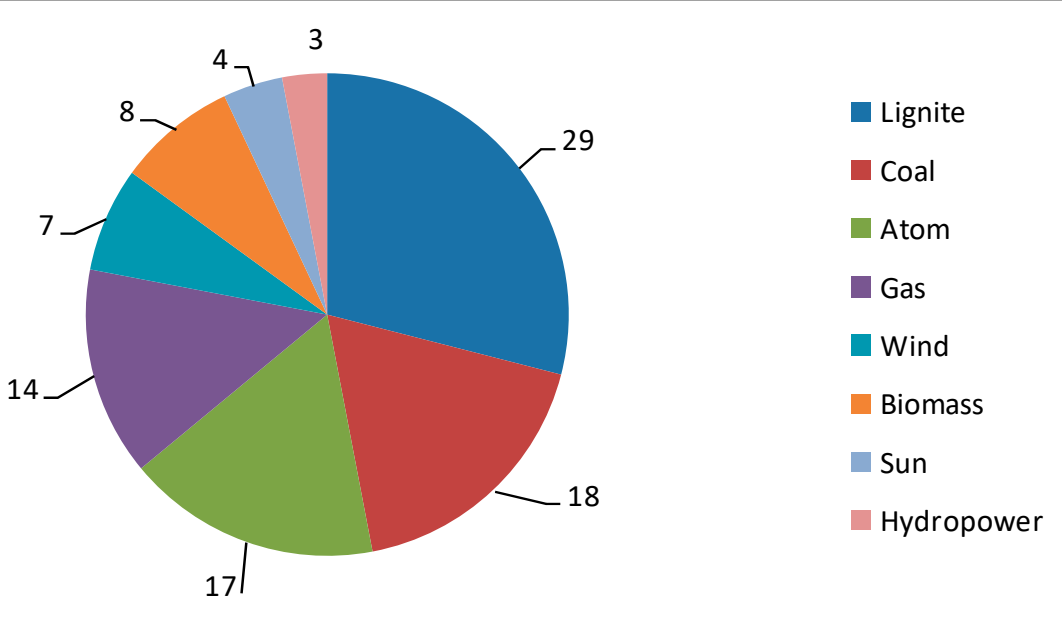

Figure 11. Electricity production by source in Germany in 2019 (in terms of percentage) [61].

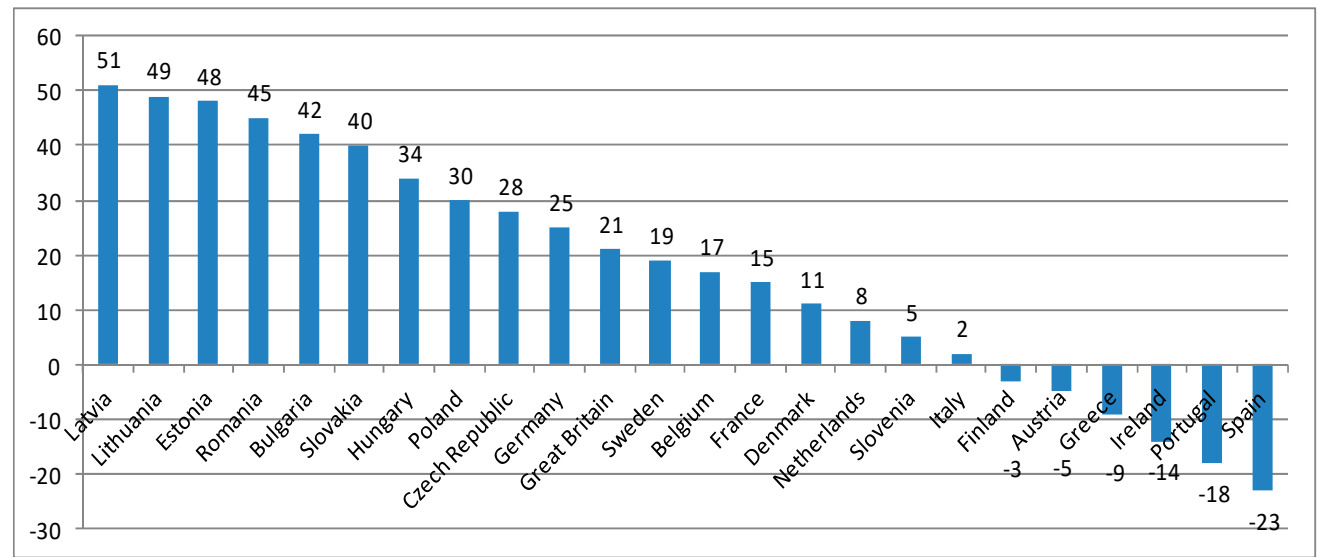

Figure 12. Implementation of greenhouse gas reduction commitments by 2030. Implementation status in 2018 (in terms of percentage) [41,52].

It is surprising that the countries of Central and Eastern Europe have the highest level of fulfillment of greenhouse gas reduction commitments [62]. The main reasons for this are the economic crisis, the loss of available coal as an energy source and the shift to low-carbon sources. Germany owes $25 \%$ of its commitments to the implementation of the largest investments thanks to subsidies from the EU [63], and the United Kingdom has simply moved part of its carbon production abroad. However, this is only a reduction in emissions within the country; globally, nothing is decreasing, and it makes the UK dependent on supplies. In contrast, despite large investments in wind power, countries such as Spain, Portugal and Ireland have high emission-increasing values. This is due to the significant increase in energy demand, and the main source of meeting these needs is gas. Countries such as Greece, Austria and Finland, due to the economic crisis, currently use the cheapest source of energy, which is coal. In practice, the European Union itself loosened the climate policy by postponing the defined goals to be achieved by 20 years, until 2050. Because the EU decision-makers realized that these values would not be achieved, due to the need to ensure, in the first place, the security of energy supplies for economies and, furthermore, to support their competitiveness. 


\section{The Development Paths of EU's Green Economy}

The analysis of the current state of the energy market and the determinants of global changes presented in the article allow one to define future trends and priorities in the EU energy strategy. The development of infrastructure within the European Union is the basis for creating a competitive and integrated EU internal market [64]. In addition, the most important element for improving the situation on the energy market in Europe is the same policy of all EU Member States. It is necessary to work out the same rules in relations with external countries for strategic supplies. For example, at the EU level, there is a proposal to jointly negotiate the prices of energy sources with external countries, for all EU countries. Unfortunately, at the moment there is a lack of implementation of ideas supporting the unity of EU countries. In the near future, by 2030, prices will be negotiated with the region of Asia Minor, including such countries as Azerbaijan, Turkmenistan and Uzbekistan, as well as Iran and Iraq. As part of the major infrastructure projects of the Southern Corridor, the most important is Nabucco, where gas would flow through Turkey, Bulgaria, Romania and Hungary to Austria, and hence would be distributed to other EU countries. The estimated capacity is 60 billion $\mathrm{m}^{3}$ [65]. In order to ensure sufficient amounts of gas for EU countries, it is planned to build a trans-Caspian gas pipeline that will connect Turkmenistan through the Caspian Sea with the Azerbaijani transmission network. Turkmenistan has the largest documented deposits among the countries of Asia Minor, namely, over 8 trillion $\mathrm{m}^{3}$, which translates into $5 \%$ of the world's resources. Diversification of supplies from Russia may occur even faster through gas pipeline connections with Norway, which is the EU's second gas supplier. Unfortunately, Polish offshore connection projects have not been implemented. Due to the failure to implement the project, Poland lost enormous opportunities for its own security of supply and the strategic dimension of the transit country [66]. The Czech Republic became convinced of the role of diversification in 2009, which, thanks to the German bus system, was able to maintain stable supplies thanks to the contract with Norway at the time when Russia stopped deliveries.

Diversification of gas supplies through new pipelines and LNG terminals is the basic method for increasing energy security. Currently, the countries of Central Europe are implementing their diversification plans by connecting to the German main lines, which will be used to transport gas from Nord Stream on a reverse basis. It is also possible to implement the Baltic Pipe project, i.e., a gas pipeline running from Denmark to Poland [67]. The European Commission awarded a subsidy to the project as part of key energy projects. The prospects for the development of the EU's energy situation largely depend on the implementation of external infrastructure investments. In the case of the implementation of South Stream by Russia, in the case of the functioning Nord Stream, along with the abandonment of independent EU projects (Nabucco, White Stream), the cause will be dependence on Russia and the creation of the so-called "Reins", which may have a strategic influence on the countries of Central and Eastern Europe in political conflicts. At the moment, the EU has blocked the South Stream project, although the situation is dynamic and changes on a regular basis. In addition, Russia claims that only four shareholders, i.e., energy companies from Russia, Italy, Germany and France, can decide to suspend the construction, and therefore indicates the culprit for this decision, namely, the EU leaders. On the other hand, Germany is increasing the capacity of Nord Stream (four lines), thanks to which up to 110 billion $\mathrm{m}^{3}$ of gas can flow annually [68]. Therefore, with Russia's continued conflict with Central and Eastern Europe and the failure to implement Nabucco, the EU may still rely on supplies from Russia, most of which will be transported via Germany. Therefore, common interests with Russia are beneficial to the German economy. It is also evident that the conflict of interests of powerful market players, as can be seen from the lack of implementation of current tasks, are blocking independent EU projects. For Central and Eastern Europe, it is important to connect with Ukraine, which has large coal reserves and can be a transit country for oil. The Odessa-Brody oil pipeline ends 100 $\mathrm{km}$ before the Polish border, and this investment is taking real shape [32]. However, it is known that such strategic decisions will take place in the international political and 
economic arenas, where we are dealing with an unstable situation as a result of the crisis and war in Ukraine. Positive implementation of strategic investments for the EU in the international arena is extremely difficult and complicated, and often exists in the absence of internal consent within the EU and in the context of the struggle for self-determination of individual Member States [43]. However, it should be noted that infrastructure connections are a geostrategic issue that will allow for the diversification of natural gas suppliers, which will be a key security for external supplies. At the same time, it will enable the transport of gas in various directions: north-south and east-west, and thus will allow for greater independence and the possibility of choosing a supplier on market terms. This will strengthen energy security in the economic dimension by opening up new purchasing opportunities on the spot market and creating a liberalized, and therefore more attractive, integrated European market.

Another extremely important issue is the shape of the EU's climate and energy policy after 2020, when the completed EU sub-targets will be assessed and $\mathrm{CO}_{2}$ emissions trading will begin to function in full. These solutions are as follows [4,33]:

- In the manufacturing industry, in installations covered by the EU ETS, the acquisition of $\mathrm{CO}_{2}$ emission allowances by way of auctioning will be introduced gradually. The share of auction-acquired permits was $20 \%$ ( $80 \%$ of permits for free) in 2013, and will increase to $70 \%$ by 2020 ;

- Broad exemptions from the above rule have been introduced for industry sectors likely to relocate production outside the EU to countries that do not have such far-reaching emission limits. Producers in these industries will be able to apply for 100\% free shares through international negotiations;

- In the electricity sector, all emission allowances will be auctioned. There are exceptions to this rule for new Member States, including Poland, which will obtain some allowances for free, and only from 2020 will all allowances be purchased by auction;

- It is assumed that at least $50 \%$ of revenues from the distribution of emission allowances will be allocated to counteracting climate change and mitigating its effects through investments in renewable energy and other low-carbon technologies, improving energy efficiency and preventing deforestation and technology transfer.

Undoubtedly, it is already clear that most countries, including Germany, would like to withdraw from the restrictive EU climate policy, which is irrelevant on a global scale.

The transport sector is another aspect of the global energy situation because no one doubts the enormous importance of the American shale revolution for the global oil market. Thanks to the development of this technology, since 2010 US oil production has increased by 3.6 million barrels per day, and at the same time the absorptive capacity of the local market has decreased by as much as 3.3 million barrels per day [15]. Canadians added their 1.5 million barrels per day thanks to the extraction of tar sands. However, the increase in global oil supply is not entirely the work of North America. Players from other regions of the world are also doing theirs. Production in the Middle East did not decrease despite the Iraq War. All of this is happening in the context of global oil consumption lowering by 5 million barrels per day [65]. Historically, oil has not been subject to natural market processes to the same extent as it now. As cars become more and more economical, the demand for oil could decline in the future, more so as the largest oil importers, i.e., the USA, Europe, China, India and Japan, will seek to break the monopoly of oil as an energy source in road transportation. It should not be forgotten that energy transition requires a change in consciousness, habits, and behaviors in society for these initiatives to be truly effective [69].

Strong increase in demand for energy from RES in the European Union will slow down due to the need to comply with international provisions on climate change or the will to support new industries in the field of RES. The pace of implementation of the idea of a global low-carbon society will remain slow. This is mainly due to the low efficiency of most RES compared to conventional energy. As a result of the greater complexity of technologies and the disadvantages of nuclear energy (danger, radioactive waste) and renewable energy 
(costly, insufficient efficiency), forecasts indicate that gas-based energy will push the global energy industry towards more carbon dioxide-free production. For the EU economy, this means greater dependence on the external market, which additionally contradicts the simultaneous achievement of the goal of reducing carbon dioxide emissions and reducing dependence on external supplies. Figure 13 shows the forecast of the International Energy Agency for the structure of primary energy consumption for 2030.

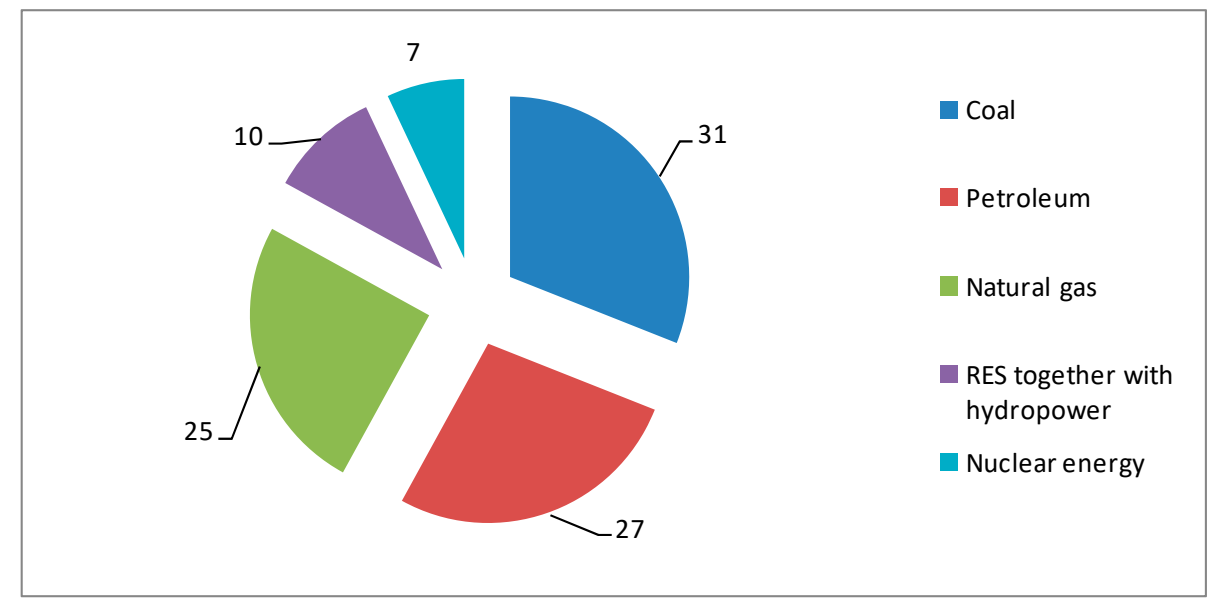

Figure 13. Forecast of the structure of primary energy used for 2030 (in terms of percentage) [41].

The forecasts presented in the Figure 13 show that by 2030 there will be no major changes in the structure of the use of energy sources, apart from the return of coal to the leading position. The possibility of using it as a chemical raw material and transport fuel will also contribute to the wide use of the most abundant and evenly distributed energy resource in the world, which is coal. In the following years of the twenty-first century, research and development of new technologies of energy generation will be of great importance for the energy situation in the world [70]. Forecasts and scenarios of all world institutions and experts in this field indicate that fossil fuels will continue to play a dominant role, especially in the time horizon up to 2050. Therefore, it is necessary to work on innovations related to technologies that will be more efficient; rational; and, at the same time, support environmental protection [71]. The integration of RES would foster reducing primary energy consumption, minimizing environmental impacts and improving technical quality $[72,73]$. Practical examples of these technologies are now functioning, so a joint effort by EU countries should be made in this regard. For example, the development of clean coal technologies allows for the achievement of higher energy efficiency of coal use (higher economic efficiency) and allows one to meet the goal of reducing greenhouse gases. Undoubtedly, the future decline in renewable energy prices due to new technologies will lead to the gradual introduction of clean energies [74]. However, at the moment it is a difficult task and, above all, too costly in relation to the need to ensure security of energy supply for economies. Therefore, even in 2050, none of the four major scenarios for the development of the global energy industry modeled by the IPCC shows significant value of using available renewable energy sources.

Meanwhile, the dependence of European Union countries on raw materials is constantly increasing. According to the Commission's forecasts, dependence on gas imports will increase to $84 \%$ and oil imports to $93 \%$ by 2030 [75]. Virtually all imports will come from several countries in the Middle East, the Caspian Basin and Russia. None of these suppliers has a liberal open market, which makes it difficult for Europe to ensure energy security. If there are no major conflicts and turbulences in the international arena, Russia will continue to play the key role of a supplier of energy resources to Europe. In addition, due to the phasing-out plan of nuclear power plants in some EU countries and due to increasingly stringent requirements for greenhouse gas emissions, the choice of gas as fuel for power plants is becoming more frequent. This raw material, delivered via pipelines, 
is usually cheaper than LNG. Russia, having an extensive infrastructure of pipelines to Europe, will be the preferred supplier for many European countries. Additionally, thanks to its geographic location and aggressive policy, Russia controls gas transit from the Caspian Sea basin. In this region, strategic partners for the EU should be Azerbaijan and Turkmenistan, which would allow for the implementation of the Nabucco infrastructure project and result in independence from Russia as a supplier of gas and oil. Additionally, the prospect of developing a partnership with countries rich in energy resources, such as Uzbekistan, Kazakhstan and Iran, would exist. In the longer term, after the conflicts have ended, the region of Iraq and Syria will gain importance. That is why Turkey will be so important as a transit country for raw materials from the above-mentioned regions. On the other hand, if the Nabucco project is not implemented, and if the South Stream project, which is competitive for this region, is implemented, Russia's position will be additionally strengthened. There will be "funnels" (Figure 14) that Russia will be able to use in political conflicts, for example, by interrupting gas supplies to Central and Eastern Europe.

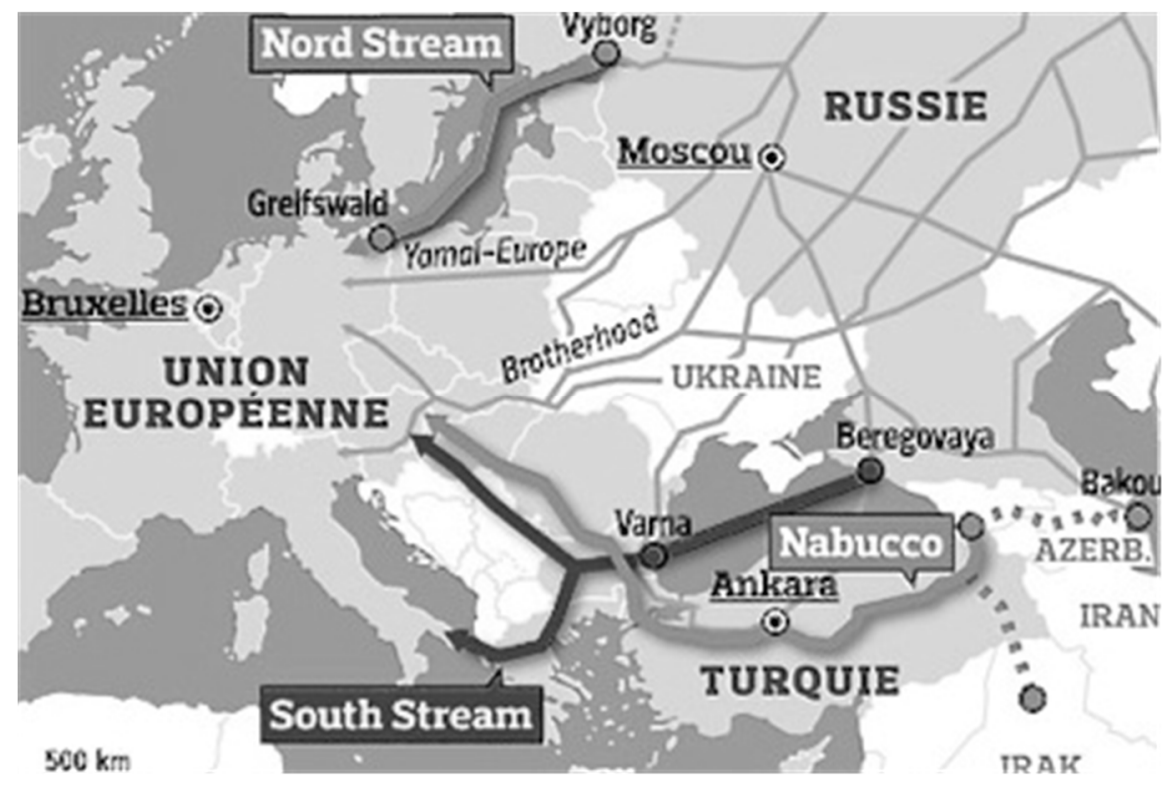

Figure 14. Connection of Nord Stream and the Nabucco and South Stream projects [76].

The geopolitical situation and EU external policy, including the implementation of strategic infrastructure projects, will have a fundamental impact on the energy market and possible solutions to many energy and climate challenges that have a direct impact on the functioning of basic areas of life $[68,77]$. So far, the EU has tried to solve the problem of growing dependence by persuading Russia to ratify the Energy Charter, in particular to sign the Transit Protocol. This solution has been unsuccessful, and Russia is unlikely to be able to ratify these documents because the country's foreign policy is built on the monopoly position of Gazprom, and it is unlikely that Russia will give this up by allowing competition. All this makes it difficult for the European Union to achieve a common and coherent position towards Russia. There is a divergence of strategic interests among EU countries [78]. Due to the lack of an alternative, some EU countries are in favor of ever closer cooperation with Russia, seeking to increase gas imports from this direction, while other countries want to reduce the percentage of Russian gas in their energy mix. As a result, some members prefer to develop bilateral relations, preferring them to common policies, which is particularly important in view of the political situation and armed conflicts. For example, through the Nord Stream gas pipeline, Germany is harming the interests of Central and Eastern European countries. Therefore, it is difficult to be optimistic when reading the ambitious proposals of the European Commission on "speaking with one voice" and at the same time observing the reality. Other European countries (such as, for example, Italy, Hungary, and soon probably several others), seeing the benefits of bilateral 
cooperation with Russia, are following in Germany's footsteps, thus increasingly erasing the idea of a common external energy policy. The geopolitical situation is being created on an ongoing basis, and it is difficult to forecast its development, although it can be noticed that the more Russia relies on military solutions, the more Western member states will see this as a threat, which in turn may lead to the true unification, with a unified position, of the entire EU. As regards the energy situation of the EU Member States, due to the lack of rich deposits of conventional raw materials in most countries, the most important problems are ensuring the security of energy supplies and energy dependence on external suppliers, especially if it is dependence on one supply direction, e.g., from Russia. At the same time, the goal of the EU is competitiveness, which is to reduce the costs of obtaining energy. Unfortunately, this is often contrary to the desire to become independent from external supplies in general due to lower costs than the possibilities of own energy sources [79]. Therefore, for a coherent policy, it is necessary to prioritize the implementation of these goals. Therefore, first of all, energy security should be ensured, which means providing the country with the necessary amount of energy at market prices (competitiveness) and only then achieving the goals of own production if there are economic reasons for it. The energy market is changing, and the aim is to create a market where prices will apply at the time of energy purchase, and not in established long-term contracts, which will create a market based on economic principles. Therefore, projects are implemented for new directions of supply and transmission routes of raw materials and for the diversification of energy sources, thanks to which the financial aspects will be decisive [80].

\section{Conclusions}

The conclusions on the 2030 climate and energy policy framework set out some figures to be achieved, for example, increasing the share of RES in total energy consumption to 20 percent at the level of the entire European Union. When setting individual targets, it will be necessary to consider each country's starting situation. An important element of the EU's climate and energy policy, and currently the greatest challenge, is the solidarity and external policy of the EU towards external countries, especially suppliers of energy sources. Despite the provisions that the Union will "fully use the available instruments to improve cooperation with energy suppliers", in practice there is no EU policy towards external countries, and negotiations are conducted at the level of individual countries or possibly several countries interested in a specific goal, often contrary to the interests of other EU Member States. The approach of the European Commission itself to the issue of the common energy policy raises many doubts [77]. In its proposals, the EC focuses on issues related to competition in the internal market and climate change and does not provide answers on how to meet equally important, or even more important, challenges faced by the EU Member States, e.g., dependence on imported oil and gas or conducting common policy towards Russia. This is especially important for Central and Eastern Europe and other developing countries as the center of gravity on liberalizing the EU energy market and low-carbon energy generation technologies may indicate a desire to strengthen the current situation in the EU regarding the leadership and strength of the Member States. The internal energy market and EU competitiveness can be seen as a desire to access developing countries' markets via stronger economies, and the raised problem of climate change can be seen as a way of selling energy technologies and the desire to stop Central and Eastern European countries from enriching with rich coal deposits.

The EU energy policy concerning the rapid increase in the share of renewable energy sources in the energy mix of the Member States adversely affects the security of energy supply and the efficiency of its production. Converting part of traditional energy to RES is currently associated with huge costs and increases dependence on imported fossil fuels. The solution itself seems to be good in the long run, but the current technological solutions have problems with effective implementation with the simultaneous existence of more effective alternatives. On the issue of nuclear energy, EU regulations did not take an unequivocal position, which gave Member States the freedom to choose how to use it as they see fit. 
This is another argument for the inconsistency in the EU energy policy. Countries such as France, Bulgaria, Slovakia, Finland and Romania are supporters of increasing the share of nuclear energy. On the other hand, Germany, Italy, Austria and Spain are completely against the use of nuclear energy due to the risk of severe consequences in the event of a nuclear accident. Due to the impossibility of implementing the current EU energy policy until 2050, in practice it can be expected that the withdrawn coal and nuclear capacities will be replaced by gas, as evidenced by new long-term contracts. Due to the location of this energy source, this will lead to an increased dependence on external resources (including Russia). At the same time, the adopted regulations do not, in practice, affect climate change because by $2030 \mathrm{EU}$ countries will consume about 10 percent the total amount of energy consumed in the world, and the developed world economies will significantly their increase the use of coal. Therefore, EU countries often deviate from the proposed greenhouse gas emission limits, especially when economies need cheap energy. Therefore, the EU energy and climate strategy is heading towards two priorities announced in the so-called a triad of goals, namely, securing energy supplies to its economy, and maintaining the competitiveness of its energy market. It is now necessary to overcome the crisis and economic stagnation also caused by the global pandemic. The proposed solution has been consistently stated: the EU's energy policy in the international arena, which in practice will actively support real European interests.

Unfortunately, the currently existing legal regulations regarding the implementation of infrastructure investments are difficult to apply and are constantly changing. This makes it difficult to apply the established rights and recommendations due to administrative, legal and social difficulties. The lack of appropriate legal regulations may lead to stagnation of the entire EU economy in the future. This is because failure to ensure energy supplies will paralyze the functioning and development of transport and trade, which will directly translate into all other sectors of the economy. Therefore, the instability of the solutions in the EU strategy, which are inadequate to the dynamically changing internal conditions and environment, is not optimistic for forecasts of economic development in the Member States. This makes it all the more necessary for the European Union to quickly develop a coherent and adequate energy policy to meet the global situation. The divergence of interests results from a whole range of historical, economic and social conditions. The legislative process in the European Union is also very slow, which creates new challenges and problems. Nevertheless, it is a positive symptom that energy policy is of a strategic nature (one of the highest priorities of the EU) for the entire EU economy, so these issues are often discussed, which provides hope for an improvement in the future. Additionally, the driving force of change for the development of a uniform and coherent EU energy policy may be international policy, where all member states have common interests. Therefore, already in the EU documents from the 2030 perspective, ensuring energy supplies for the economy is again becoming a priority. In this regard, efforts are being made to intensify the use of the EU's internal resources, improve energy efficiency and create a uniform international policy for the benefit of all EU countries.

In recent years, energy security has become one of the key topics in the discussion on the national security of states. According to the calculations of the European Commission, without undertaking new tasks in the energy policy, the dependence of the European Union on energy imports will increase to 70 percent in the next $20-30$ years [73], and most of these imports will come from Russia. The lack of a coherent energy policy has become one of the greatest challenges for the EU. However, everyone agrees as to the advantages of innovative low-emission technologies from various energy sources, which undoubtedly introduces a modern solution allowing for sustainable energy. This is because it contributes to the creation of a more competitive and safer Europe from the point of view of the green economy.

Author Contributions: Conceptualization, I.M., H.W., B.W., M.S., M.G., J.B., K.K. and J.K.; methodology, I.M., H.W., B.W., M.S., M.G., J.B., K.K. and J.K.; validation, I.M., H.W., B.W., M.S., M.G., J.B., K.K. and J.K.; formal analysis, I.M., H.W., B.W., M.S., M.G., J.B., K.K. and J.K.; resources, I.M., H.W., 
B.W., M.S., M.G., J.B., K.K. and J.K.; data curation, I.M., H.W., B.W., M.S., M.G., J.B., K.K. and J.K.; writing—original draft preparation, I.M., H.W., B.W., M.S., M.G., J.B., K.K. and J.K.; writing-review and editing, I.M., H.W., B.W., M.S., M.G. and J.B.; visualization, I.M., H.W., B.W., M.S. and M.G. All authors have read and agreed to the published version of the manuscript.

Funding: This research was funded by: Natolin European Center grant for "summer research" at the Library of the European University Institute in Florence. The project was financed within the framework of the program of the Minister of Science and Higher Education in Poland under the name "Regional Excellence Initiative" in the years 2019-2022, project number 001/RID/2018/19, the amount of financing PLN 10684000.00.

Institutional Review Board Statement: Not Applicable.

Informed Consent Statement: Not Applicable.

Data Availability Statement: No data support.

Acknowledgments: Many thanks to Sebastian Majewski, Beata Filipiak and Leon Dorozik for scientific support and Justyna Miciuła for spiritual support.

Conflicts of Interest: The authors declare no conflict of interest.

\section{References}

1. European Union Legal Assets Database. Available online: http://europa.eu/legislation_summaries/energy/index_en.htm (accessed on 18 May 2021).

2. Horodziejczyk, D. New Energy Policy of the European Union. BAS Studies of the Chancellery of the Sejm; No. 12, Selected Social and Economic Issues; Energy Policy Institute: Warsaw, Poland, 2008.

3. Communication from the Commission to the European Council and the European Parliament, European Energy Policy; COM (2007) 1; European Commission: Brussels, Belgium, 2007.

4. European Commission. European Energy and Transport Trends to 2030-Update 2007; Publications Office of the European Union: Brussels, Belgium, 2008.

5. Buchan, D. Energy and Climate Change: Europe at The Crossroads; Oxford University Press for the Oxford Institute for Energy Studies: New York, NY, USA, 2009.

6. $\quad$ Leveque, F.; Glachant, J.M.; Barquin, J.; Holz, F.; Nuttall, W. Security of Energy Supply in Europe Natural Gas, Nuclear and Hydrogen; Loyola de Palacio Series on European Energy Policy; Edward Elgar Pubilshing Limited: Cheltenham, UK, 2014.

7. Tatarzyński, M. Energy Policy of the European Union; National Security: Warsaw, Poland, 2007.

8. Maśloch, P.; Miciuła, I.; Wojtaszek, H. European Union Climate and Energy Policy Based on an Analysis of Issued Legal Acts. In Proceedings of the 5th International Conference on European Integration 2020, Ostrava, Czech Republic, 3-4 December 2020; Staníčková, M., Melecký, L., Doleželová, P., Powadová, T., Eds.; VŠB Technical University of Ostrava: Ostrava, Czechy, 2020; pp. 600-609.

9. Dannreuther, R.; Ostrowski, W. Global Resources—Conflict and Cooperation; Palgrave MacMillan: Hampshire, UK, 2013.

10. Nematchoua, M.K.; Asadi, S.; Reiter, S. Influence of energy mix on the life cycle of an eco-neighborhood, a case study of 150 countries. Renew. Energy 2020, 162, 81-97. [CrossRef]

11. Chateau, B.; Rossetti di Valdalbero, D. World and European Energy and Environment Transition Outlook; European Commission: Brussels, Belgium, 2011.

12. Miciuła, I.; Stępień, P. Analysis of the Global Market of Energy Resources. In Eurasian Economic Perspectives. Eurasian Studies in Business and Economics; Bilgin, M., Danis, H., Demir, E., Can, U., Eds.; Springer: Cham, Germany, 2019; Volume 10. [CrossRef]

13. CVCE EU. Available online: http:/ / www.cvce.eu/obj/en-11a21305-941e-49d7-a171-ed5be548cd58 (accessed on 12 June 2021).

14. Hambura, S.; Muszyński, M. Treaties on the European Union; C.H.BECK Hart: Berlin, Germany, 2005.

15. Chick, M. Electricity and Energy Policy in Britain, France and the United States since 1945; Edward Elgar: Cheltenham, UK; Northampton, MA, USA, 2007.

16. Euracoal. Available online: http://www.euracoal.be/ (accessed on 18 December 2020).

17. White Paper. An Energy Policy for the European Union; COM(1995) 682 Final; European Commission: Brussels, Belgium, 1995.

18. European Commission. Green Paper. 2030 Climate and Energy Policy Framework; COM (2013), 169 Final; European Commission: Brussels, Belgium, 2013.

19. Glachant, J.M.; Leveque, F. Electricity Reform in Europe towards a Single Energy Marke; Loyola de Palacio Series on European Energy Policy; Edward Elgar Pubilshing Limited: Cheltenham, UK, 2014.

20. European Commission. Available online: http://europa.eu/legislation_summaries/energy/index_pl.htm (accessed on 30 April 2020).

21. European Commission. European Energy and Transport Trends to 2030-Update 2009; EC: Brussels, Belgium, 2010.

22. Miciuła, I. Energy mix as the basic regularity of the principles of sustainable development. Econ. Sci. Rural. Dev. 2019, 52, 370-378.

23. Chevalier, J.M. The New Energy Crisis—Climate, Economics and Geopolitics; MacMillan: New York, NY, USA, 2009. 
24. Energy for the future: Renewable sources of energy. In Green Paper for a Community Strategy; 20.11.1996. COM. (96) 576 Final; European Commission: Brussels, Belgium, 1996.

25. European Commission. White Paper for a Community Strategy; COM (97) 599 Final; European Commission: Brussels, Belgium, 1997.

26. Oettinger, G. UE Proposes Tough Energy Efficiency Package. Business Green, 8 March 2011.

27. Barcz, J. European Union Law. System Issues; PWN: Warsaw, Poland, 2006.

28. European Union Law (1992, Last Update 21.03.2018). Treaty of Maastricht on European Union. 2018. Available online: http: / / europa.eu/legislation_summaries/institutional_affairs/treaties_maastricht_en.htm (accessed on 11 May 2021).

29. Miciuła, I.; Miciuła, K. Renewable Energy and Its Financial Aspects as an Element of the Sustainable Development of Poland; Scientific Papers of Wrocław University of Economics No. 330; Wrocław University of Economics: Wrocław, Poland, 2014 ; pp. $239-247$.

30. Powers, L.W. The World Energy Dilemma; PennWell: Nashville, TN, USA, 2012.

31. Glachant, J.M.; Finon, D.; Hauteclocque, A. Competition, Contracts and Electricity Markets—A New Perspective; Firenze: Loyola de Palacio Series on European Energy Policy; Edward Elgar Pubilshing Limited: Cheltenham, UK, 2014.

32. Miciuła, I.; Stepień, P. The Impact of Current EU Climate and Energy Policies on the Economy of Poland. Pol. J. Environ. Stud. 2019, 28, 2273-2280. [CrossRef]

33. The Economist. The Fuel of the Future: Environmental Lunacy in Europe. Available online: http:/ / www.economist.com/news/ business/21575771-environmental-lunacy-europe-fuel-future (accessed on 10 September 2021).

34. Fazioli, R.; Pantaleone, F. Macroeconomic Factors Influencing Public Policy Strategies for Blue and Green Hydrogen. Energies 2021, 14, 7938. [CrossRef]

35. European Commission. Communication from the Commission to the European Parliament, the Council, the European Economic and Social Committee and the Committee of the Regions: A hydrogen strategy for a climate-neutral Europe. In Global CCS Institute: Global Status of CCS 2020; European Commission: Brussels, Belgium, 2020.

36. Thaler, H. Forecasts for the Global Energy Market; Frost \& Sullivan: London, UK, 2014.

37. Pach-Gurgul, A. The energy-climate package and realisation of its objectives within the context of the sustainable development of the European Union. Cent. Eur. Rev. Econ. Financ. 2015, 10, 75-90.

38. Dyer, H.; Trombetta, M.J. International Handbook of Energy Security; Edward Elgar: Cheltenham, UK, 2013.

39. Späth, P.; Rohracher, H. 'Energy regions': The transformative power of regional discourses on socio-technical futures. Res. Policy 2010, 39, 449-458. [CrossRef]

40. Vavrek, R.; Chovancova, J. Assessment of economic and environmental energy performance of EU countries using CV-TOPSIS technique. Ecol. Indic. 2019, 106, 105519. [CrossRef]

41. International Energy Agency, Key World Energy Statistics 2020. Available online: http:/ / www.iea.org/publications/freepublications/ publication/ (accessed on 22 July 2021).

42. BP Statistical Review of World Energy. Available online: https://www.bp.com/en/global/corporate/energy-economics/ statistical-review-of-world-energy.html (accessed on 14 September 2021).

43. Balitskiy, S.; Bilan, Y.; Strielkowski, W. Energy Security and Economic Growth in the European Union. J. Secur. Sustain. Issues 2014, 4, 123-130. [CrossRef]

44. Stępień, P.; Miciuła, I. Liberalization of the Polish energy market and the EU commitments. Czech J. Soc. Sci. Bus. Econ. 2016, 5, 25.

45. Eurostat. Available online: http:/ / ec.europa.eu/energy/statistics (accessed on 10 September 2021).

46. Moran, D.; Russell, J. Energy Security and Global Politics, Routledge Global Security Studies; Taylor \& Francis Group: London, UK; New York, NY, USA, 2009.

47. Energy Information Administration. International Energy Annual; Energy Information Administration: Washington, DC, USA, 2020.

48. NaftaGaz Analysis Center. Available online: NaftaGaz.pl (accessed on 12 September 2021).

49. International Atomic Energy Agency. Available online: http:/ /www.iaea.org (accessed on 22 September 2021).

50. Salata, F.; Ciancio, V.; Dell'Olmo, J.; Golasi, I.; Palusci, O. Effects of local conditions on the multi-variable and multi-objective energy optimization of residential buildings using genetic algorithms. Appl. Energy 2020, 260, 114289. [CrossRef]

51. Murphy, A.; Abramowitz, U.S. Energy Information Administration, Independent Statistics \& Analysis. Available online: http:/ / www.eia.gov / todayinenergy / detail.cfm?id=18071 (accessed on 3 September 2021).

52. Enerdata. Global Energy Statistical Yearbook 2020. Available online: https:/ / yearbook.enerdata.net/ (accessed on 3 September 2021).

53. Derdevet, M. L'Europe en Panne D'energie; Descartes \& Cie: Paris, France, 2009.

54. Maśloch, P.; Maśloch, G.; Kuźmiński, Ł.; Wojtaszek, H.; Miciuła, I. Autonomous energy regions as a proposed choice of selecting selected EU regions-Aspects of their creation and management. Energies 2020, 13, 6444. [CrossRef]

55. Eurostat. Available online: http:/ / ec.europa.eu/eurostat/web/energy/statistics-illustrated (accessed on 20 July 2021).

56. Global Warming. Available online: http:/ / www.globalwarming.org.in (accessed on 1 September 2021).

57. Molino, A.; Mehariya, S.; Karatza, D.; Chianese, S.; Iovine, A.; Casella, P.; Marino, T.; Musmarra, D. Bench-Scale Cultivation of Microalgae Scenedesmus almeriensis for $\mathrm{CO}_{2}$ Capture and Lutein Production. Energies 2019, 12, 2806. [CrossRef]

58. Magrini, A.; Lentini, G.; Cuman, S.; Bodrato, A.; Marenco, L. From nearly zero energy buildings (NZEB) to positive energy buildings (PEB): The next challenge-The most recent European trends with some notes on the energy analysis of a forerunner PEB example. Dev. Built Environ. 2020, 3, 100019. [CrossRef] 
59. Research Institute: Agora Energiewende. Available online: http://www.agora-energiewende.de/Paradox.pdf (accessed on 7 June 2021).

60. Lumbreras, M.; Garay, R. Energy \& economic assessment of façade-integrated solar thermal systems combined with ultra-low temperature district-heating. Renew. Energy 2020, 159, 1000-1014.

61. Bloomberg New Energy Finance; BDEW: Berlin, Germany, 2020.

62. Mann, D.; Yeung, C.; Habets, R.; Vroon, Z.; Buskens, P. Comparative Building Energy Simulation Study of Static and Thermochromically Adaptive Energy-Efficient Glazing in Various Climate Regions. Energies 2020, 13, 2842. [CrossRef]

63. Valdovinos-García, E.M.; Barajas-Fernández, J.; Olán-Acosta, M.Á.; Petriz-Prieto, M.A.; Guzmán-López, A.; Bravo-Sánchez, M.G. Techno-Economic Study of $\mathrm{CO}_{2}$ Capture of a Thermoelectric Plant Using Microalgae (Chlorella vulgaris) for Production of Feedstock for Bioenergy. Energies 2020, 13, 413. [CrossRef]

64. Cadoret, I.; Padovano, F. The political drivers of renewable energies policies. Energy Econ. 2016, 56, 261-269. [CrossRef]

65. Global Economy, World Economy. 2021. Available online: https:/ / www.theglobaleconomy.com/ (accessed on 15 November 2021).

66. Brodny, J.; Tutak, M.; Saki, S.A. Forecasting the Structure of Energy Production from Renewable Energy Sources and Biofuels in Poland. Energies 2020, 13, 2539. [CrossRef]

67. Nicolli, F.; Vona, F. Heterogeneous policies, heterogeneous technologies: The case of renewable energy. Energy Econ. 2016, 56, 190-204. [CrossRef]

68. Stavytskyy, A.; Kharlamova, G.; Giedraitis, V.; Šumskis, V. Estimating the interrelation between energy security and macroeconomic factors in European countries. J. Int. Stud. 2018, 11, 217-238. [CrossRef]

69. Sánchez-Pantoja, N.; Vidal, R.; Pastor, M.C. EU-Funded Projects with Actual Implementation of Renewable Energies in Cities. Analysis of Their Concern for Aesthetic Impact. Energies 2021, 14, 1627. [CrossRef]

70. Luo, X.; Wang, J.; Dooner, M.; Clarke, J. Overview of current development in electrical energy storage technologies and the application potential in power system operation. Appl. Energy 2015, 137, 511-536. [CrossRef]

71. Telenga-Kopyczyńska, J.; Jonek-Kowalska, I. Algorithm for Selecting Best Available Techniques in Polish Coking Plants Supporting Multi-Criteria Investment Decisions in European Environmental Conditions. Energies 2021, 14, 2631. [CrossRef]

72. Jansen, M.; Staffell, I.; Kitzing, L.; Quoilin, S.; Wiggelinkhuizen, E.; Bulder, B.; Riepin, I.; Müsgens, F. Offshore wind competitiveness in mature markets without subsidy. Nat. Energy 2020, 5, 614-622. [CrossRef]

73. Lucchi, E.; Polo Lopez, C.S.; Franco, G. A conceptual framework on the integration of solar energy systems in heritage sites and buildings. IOP Conf. Ser. Mater. Sci. Eng. 2020, 949, 012113. [CrossRef]

74. EU. Horizon 2020 Challenge 10. Secure, Clean and Efficient Energy: Work Programme 2018-2020; EU: Brussels, Belgium, 2018.

75. European Commission. Clean Energy for All Europeans; European Commission: Brussels, Belgium, 2019.

76. Available online: http://www.fruits-rouges.org/wp-content/uploads/Les-gazoducs-North-Stream-South-Stream-et-Nabucco1 .jpg (accessed on 25 August 2021).

77. Miciuła, I.; Wojtaszek, H.; Bazan, M.; Janiczek, T.; Włodarczyk, B.; Kabus, J.; Kana, R. Management of the Energy Mix and Emissivity of Individual Economies in the European Union as a Challenge of the Modern World Climate. Energies 2020, 13, 5191. [CrossRef]

78. Ding, H.; Zhou, D.; Zhou, P. Optimal policy supports for renewable energy technology development: A dynamic programming model. Energy Econ. 2020, 92, 104765. [CrossRef]

79. Noailly, J.; Smeets, R. Financing Energy Innovation: Internal Finance and the Direction of Technical Change. Environ. Resour. Econ. 2021, 69, 1-25. [CrossRef]

80. Safarzyńska, K.; Bergh, J.C.V.D. Financial stability at risk due to investing rapidly in renewable energy. Energy Policy 2017, 108, 12-20. [CrossRef] 